\title{
Effects of seawater-pH and biomineralization on the boron isotopic composition of deep-sea bamboo corals
}

\author{
Jesse R. Farmer ${ }^{\mathrm{a}, *}$, Bärbel Hönisch ${ }^{\mathrm{a}}$, Laura F. Robinson ${ }^{\mathrm{b}, \mathrm{c}}$, Tessa M. Hill ${ }^{\mathrm{d}, \mathrm{e}}$ \\ ${ }^{a}$ Earth and Environmental Sciences and Lamont-Doherty Earth Observatory of Columbia University, New York, NY 10027, USA \\ ${ }^{\mathrm{b}}$ School of Earth Sciences, University of Bristol, Bristol BS8 1JA, UK \\ ${ }^{\mathrm{c}}$ Marine Chemistry and Geochemistry, Woods Hole Oceanographic Institution, Woods Hole, MA 02543, USA \\ ${ }^{\mathrm{d}}$ Earth and Planetary Sciences, University of California-Davis, Davis, CA 95616, USA \\ ${ }^{\mathrm{e}}$ Bodega Marine Laboratory, University of California-Davis, Bodega Bay, CA 94923, USA
}

Received 19 July 2014; accepted in revised form 14 January 2015; Available online 7 February 2015

\begin{abstract}
The ocean is currently absorbing excess carbon from anthropogenic emissions, leading to reduced seawater-pH (termed 'ocean acidification'). Instrumental records of ocean acidification are unavailable from well-ventilated areas of the deep ocean, necessitating proxy records to improve spatio-temporal understanding on the rate and magnitude of deep ocean acidification. Here we investigate boron, carbon, and oxygen isotopes on live-collected deep-sea bamboo corals (genus Keratoisis) from a $\mathrm{pH}_{\text {tot }}$ range of 7.5-8.1. These analyses are used to explore the potential for using bamboo coral skeletons as archives of past deep-sea $\mathrm{pH}$ and to trace anthropogenic acidification in the subsurface North Atlantic Ocean (850-2000 m water depth). Boron isotope ratios of the most recently secreted calcite of bamboo coral skeletons are close to the calculated isotopic composition of borate anion in seawater $\left(\delta^{11} \mathrm{~B}_{\text {borate }}\right)$ for North Atlantic corals, and $1-2 \%$ higher than $\delta^{11} \mathrm{~B}_{\text {borate }}$ for Pacific corals. Within individual coral skeletons, carbon and oxygen isotopes correlate positively and linearly, a feature associated with vital effects during coral calcification. $\delta^{11} \mathrm{~B}$ variability of $0.5-2 \%$ is observed within single specimens, which exceeds the expected anthropogenic trend in modern North Atlantic corals. $\delta^{11} \mathrm{~B}$ values are generally elevated in Pacific corals relative to $\delta^{11} \mathrm{~B}_{\mathrm{borate}}$, which may reflect $\mathrm{pH}$-driven physiological processes aiding coral calcification in environments unfavorable for calcite precipitation. Elevated $\delta^{11} \mathrm{~B}$ values are also observed proximal to the central axis in multiple Atlantic and Pacific specimens, relative to $\delta^{11} \mathrm{~B}_{\text {borate, }}$, which might reflect ontogenetic variability in calcification rates. Although the observed boron isotope variability is too large to resolve the present anthropogenic ocean acidification signal at the studied depths in the North Atlantic ( $\sim 0.03-0.07 \mathrm{pH}$ units), $\mathrm{pH}$ changes $\geqslant 0.1$ units might still be reconstructed using $\delta^{11} \mathrm{~B}$ measurements in bamboo corals.

(C) 2015 Elsevier Ltd. All rights reserved.
\end{abstract}

\section{INTRODUCTION}

The ocean is the largest exchangeable carbon reservoir in the global carbon cycle and represents an important sink for anthropogenic carbon $\left(\mathrm{C}_{\mathrm{ant}}\right)$ emissions (Gruber, 1998; Sabine et al., 2004; Khatiwala et al., 2009). The vast

\footnotetext{
* Corresponding author at: 61 Route $9 \mathrm{~W}$ Box 1000, Palisades, NY 10964, USA. Tel.: +1 (845) 365 8926; fax: +1 (845) 3658155.

E-mail address: jfarmer@1deo.columbia.edu (J.R. Farmer).
}

majority of the ocean's carbon is stored below the mixed layer in the intermediate and deep ocean, which are enriched in dissolved inorganic carbon (DIC) due to the active export of carbon from the surface ocean by physical and biological processes (e.g., Sigman et al., 2010). Emissions of anthropogenic carbon dioxide $\left(\mathrm{CO}_{2}\right)$ since the onset of the industrial era and air-sea gas exchange have resulted in a large input of $\mathrm{C}_{\text {ant }}$ to well-ventilated areas of the deep sea (Sabine et al., 2004; Wanninkhof et al., 2013). The net result of this $C_{a n t}$ pulse is a reduction in 
seawater $\mathrm{pH}$ termed 'ocean acidification' (e.g., Caldeira and Wickett, 2003; Feely et al., 2004; Doney et al., 2009).

Instrumental records of ocean acidification are limited in length and spatial coverage. Only three continuous time series of seawater carbonate system observations with $>10$ years of coverage are available for the surface ocean (Station ALOHA: Dore et al., 2009; BATS/Station S: Bates, 2007; ESOTC: González-Dávila et al., 2010). Similar records are not available for the intermediate and deep ocean; instead, $\mathrm{pH}$ changes must be inferred from back-calculated, tracer-based, or modeled estimates of $\mathrm{C}_{\text {ant }}$ inventories (Sabine et al., 2004; Khatiwala et al., 2009; Sabine and Tanhua, 2010). Paleoceanographic records extracted from surface corals using the boron isotope proxy can potentially supplement limited instrumental $\mathrm{pH}$ data for the surface ocean (Pelejero et al., 2005; Wei et al., 2009). In the intermediate and deep ocean, however, applications of boron proxies $\left(\delta^{11} \mathrm{~B}, \mathrm{~B} / \mathrm{Ca}\right)$ in epifaunal benthic foraminifera (e.g., Hönisch et al., 2008; Yu et al., 2010; Rae et al., 2011; Raitzsch et al., 2011) are better suited to longer timescales than the current anthropogenic perturbation, due to bioturbation and low accumulation rates of deepsea sediments.

Deep-sea corals (DSC) potentially provide new opportunities to reveal deep-sea conditions from highly resolved records secreted over the lifespan of the coral (ranging from years to millennia, see review in Robinson et al., 2014). Previous studies have shown promise for DSC skeletal-based proxy records of ocean circulation and ventilation (Adkins et al., 1998; Frank et al., 2004; Robinson et al., 2005; Sherwood et al., 2008; van de Flierdt et al., 2010; Burke and Robinson, 2012), biological productivity and nutrient concentrations (Sherwood et al., 2005, 2011; Montagna et al., 2006; LaVigne et al., 2011; Anagnostou et al., 2011), temperature (Smith et al., 2000; Thresher et al., 2004, 2010; Lutringer et al., 2005; Case et al., 2010; Hill et al., 2011; Kimball et al., 2014; Montagna et al., 2014), and isotopic and elemental properties of seawater (Rollion-Bard et al., 2009; Hill et al., 2012). However, reconstructions of deep-sea carbonate chemistry from boron proxies in DSC have proven challenging. Specifically, boron isotope studies in scleractinian DSC (subclass Hexacorallia) suggest physiological processes related to biomineralization overprint environmental information (Blamart et al., 2007; Anagnostou et al., 2012; McCulloch et al., 2012).

Deep-sea gorgonian corals (subclass Octocorallia) have recently generated interest as potential paleoceanographic archives. Gorgonian corals of the family Isididae are long lived (up to several centuries, Roark et al., 2005; Thresher, 2009) and globally distributed in intermediate to deep waters (Watling et al., 2011), making them attractive targets for proxy calibration and paleoceanographic reconstructions (Thresher et al., 2004; Sherwood et al., 2008; Hill et al., 2011, 2012; LaVigne et al., 2011). To date, however, there have been no studies on the feasibility of carbonate system reconstructions from boron proxies in deep-sea gorgonian corals. Here we present results from the first investigation of boron isotopes in deep-sea gorgonian corals (genus Keratoisis), and evaluate controls on their boron isotopic composition using coupled stable isotope $\left(\delta^{13} \mathrm{C}\right.$ and $\left.\delta^{18} \mathrm{O}\right)$ measurements. We compare Keratoisis boron isotope ratios in a suite of modern specimens to hydrographic $\mathrm{pH}$ measurements, and test whether isotopic time-series derived from individual North Atlantic corals reflect projections of seawater-pH change due to $\mathrm{C}_{\mathrm{ant}}$ addition.

\section{MATERIALS AND METHODS}

\subsection{Bamboo coral morphology and biomineralization}

Isidiid gorgonian corals, named "bamboo corals" for their visual resemblance to bamboo, grow a solid axial skeleton composed of non-scleritic calcareous material, surrounded by a relatively thin coenenchyme with rod-shaped sclerites longitudinally arranged on the polyps (Watling et al., 2011). Bamboo coral axial skeletons are characterized by alternating high- $\mathrm{Mg}$ calcitic internodes (7-10 $\mathrm{mol} \%$ $\mathrm{MgCO}_{3}$, Noé and Dullo, 2006) and organic nodes composed of gorgonin, a collagen-like protein (Fig. 1). Crosssections through the internodes reveal visual light-dark banding attributed to the orientation and relative organic content of $\mathrm{Mg}$-calcitic crystal bundles (fascicles) (Noé and Dullo, 2006), with the strength and symmetry of banding varying within and between specimens (Fig. 1b-d). The interior of the internode is occupied by a central axis that varies from an open, cylindrical channel (Fig. 1c) to a darkly colored, calcified or organic-filled region (Fig. 1b). At the microstructural scale, bamboo coral internodes do not exhibit centers of calcification or density banding (as evidenced from X-radiographs, Noé and Dullo, 2006), both fundamental structural features of scleractinian corals (Ogilvie, 1896; see also Cohen and McConnaughey, 2003).

Distinct differences in both skeletal microstructures and composition between calcitic bamboo corals and aragonitic scleractinian corals imply divergence in calcification mechanisms, which therefore distinguish the sampling strategy for each coral type. Gorgonian coral biomineralization is poorly understood, particularly in comparison to the wealth of geochemical approaches used to infer biomineralization mechanisms in scleractinian corals (which are nonetheless debated, e.g., McConnaughey, 1989; Adkins et al., 2003; Cohen and McConnaughey, 2003; RollionBard et al., 2003a,b; Sinclair, 2005; Blamart et al., 2007). Noé and Dullo (2006) proposed a biomineralization mechanism for bamboo corals whereby gorgonin serves as a structural framework for a $\mathrm{Ca}^{2+}$-binding soluble glycoprotein monolayer that facilitates crystal nucleation. Although this mechanism is broadly similar to organic matrix-mediated calcification mechanisms proposed for scleractinian corals (e.g., Cohen and McConnaughey, 2003; Allemand et al., 2011), the geochemical effects of such a mechanism, and more broadly, the geochemical consequences of dissimilarities between scleractinian and gorgonian calcification, are largely unknown (e.g., Kimball et al., 2014). Consequently, our sampling strategy follows simple visual structural features, as described below. 


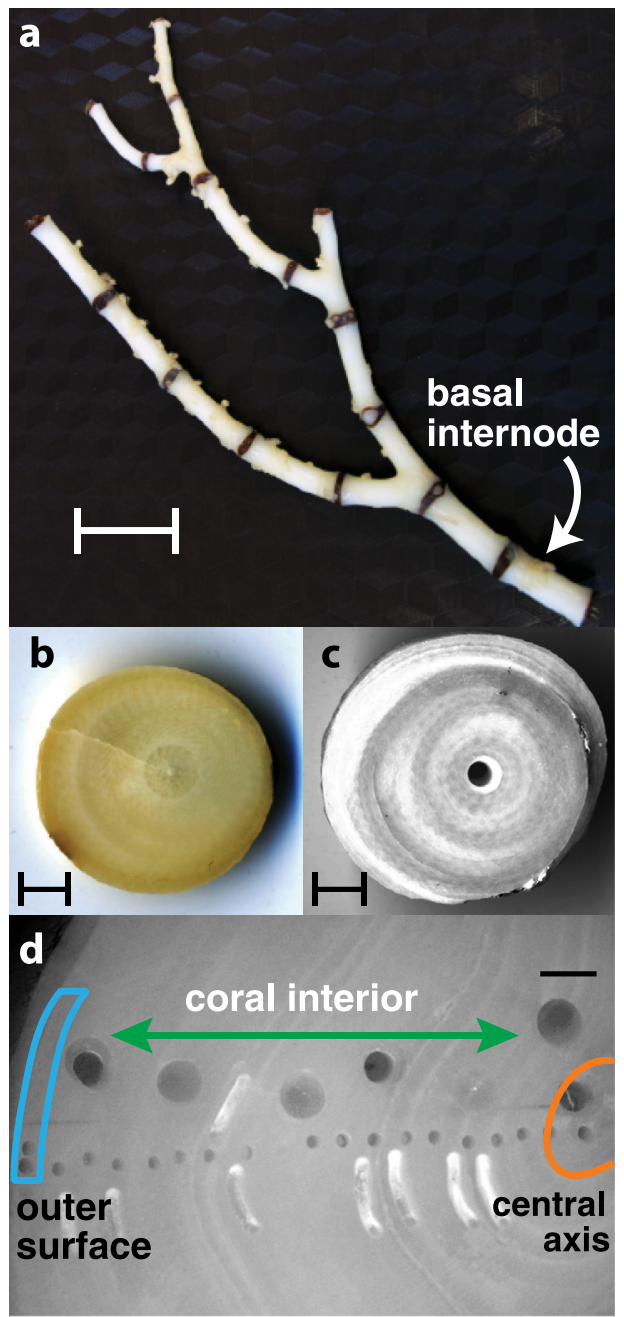

Fig. 1. Images of Keratoisis bamboo corals. (a) White calcite internodes and dark organic nodes, scale bar is $5 \mathrm{~cm}$ (Specimen USNM57439). (b) True color image of internode cross-section; scale bar is $3 \mathrm{~mm}$ (Specimen YPM37031B). (c) High-contrast filtered grayscale image of internode cross-section; scale bar is $3 \mathrm{~mm}$ (Specimen USNM1004643). (d) High-contrast filtered grayscale image of internode cross-section sampled in transect; scale bar is $2 \mathrm{~mm}$ (Specimen T668-A13). Colored regions in (d) represent transect sampling regions referred to in Fig. 7: orange is the ontogenetically oldest calcite surrounding the internode central axis; blue is the ontogenetically youngest calcite on the distal surface; green is the coral interior. (For interpretation of the references to color in this figure legend, the reader is referred to the web version of this article.)

\subsection{Bamboo coral specimens}

Bamboo coral specimens covering a broad range of ocean $\mathrm{pH}_{\text {tot }}$ (7.5-8.1, Fig. 2 and Table 1) were loaned from the Smithsonian National Museum of Natural History's Department of Invertebrate Zoology, the Yale Peabody Museum of Natural History's Division of Invertebrate Zoology, and from specimens collected by the Monterey Bay Aquarium Research Institute's Seamounts 2004 and 2007 expeditions to the California margin (Hill et al., 2011, 2012). All specimens were identified as genus
Keratoisis in museum collections, although this genus requires taxonomic revision (Watling et al., 2011). North Atlantic Ocean specimens belong to two temporally distinct assemblages: one set is derived from trawl operations by the United States Fish Commission in the late 19th century off the northeastern coast of the United States (Verrill, 1885), with more recent specimens collected by trawl in the vicinity of Bear Seamount off the northeastern United States during the NOAA Mountains in the Sea programs in 2003 and 2004 (Fig. 2b). Modern specimens possessed intact polyps on the coral surface, indicating they were alive at the time of collection. All specimens were screened for diagenetic alteration or bioerosion by visual inspection of thick sections under reflected light microscopy. Specimens did not show evidence for either diagenesis or bioerosion, consistent with previous observations of structural preservation in modern and subrecent Keratoisis specimens (Noé and Dullo, 2006).

Calcite sections of $2-4 \mathrm{~mm}$ thickness were cut from the basal internode of each specimen and polished. Calcite subsamples were obtained by drilling within visual growth bands using either a Merchantek ${ }^{\circledR}$ MicroMill with a $0.5 \mathrm{~mm}$ tungsten carbide drill bit or a Sears ${ }^{\circledR}$ variable-speed rotary tool with a $1.0 \mathrm{~mm}$ diamond burr (Fig. 1d). Average sample spacing along the radial growth direction was approximately $1-3 \mathrm{~mm}$.

\subsection{Hydrographic data and boron isotopes in seawater}

Temperature, salinity, alkalinity, and dissolved inorganic carbon (DIC) data were obtained from the nearest available World Ocean Circulation Experiment (WOCE) or Transient Tracers in the Ocean (TTO) hydrographic station to each coral collection location (Table 1). Seawater $\mathrm{pH}$ was established for each coral location using hydrographic data and CO2sys MATLAB version 1.1 (van Heuven et al., 2011), with first and second dissociation constants for carbonic acid $\left(K_{1}\right.$ and $\left.K_{2}\right)$ from Lueker et al. (2000). Uncertainty in hydrographic data for each coral location was estimated from ranges of temperature, salinity, alkalinity and DIC within a $4^{\circ}$ latitude/longitude and $\pm 100 \mathrm{~m}$ depth box of our coral collection locations and depths in the GLODAP Gridded Database (Key et al., 2004; see Anagnostou et al., 2012). Temperature and salinity uncertainty averaged $\pm 0.5^{\circ} \mathrm{C}$ and \pm 0.1 , respectively, for each coral collection location. Uncertainty in $\mathrm{pH}$ was estimated as the $2 \sigma$ of $\mathrm{pH}$ calculated from ranges of alkalinity and DIC from each grid box using hydrographic temperature and salinity data from each coral collection location. Seawater $\mathrm{pH}$ at the time of collection for North Atlantic corals from the 19th century was estimated by subtracting cumulative $C_{a n t}$ concentrations (from Khatiwala et al., 2009) from hydrographic DIC data, and assuming that hydrographic temperature, salinity, and alkalinity were unchanged. Uncertainty in $\mathrm{C}_{\text {ant }}$ inventories was estimated at $\pm 20 \%$ following Khatiwala et al. (2009), which translates to a small additional pH uncertainty $(<0.01 \mathrm{pH}$ units) that was added to uncertainty estimates for these collection locations.

In seawater, boron predominantly exists as $\mathrm{B}(\mathrm{OH})_{3}$ (uncharged boric acid) and $\mathrm{B}(\mathrm{OH})_{4}^{-}$(borate anion), with 

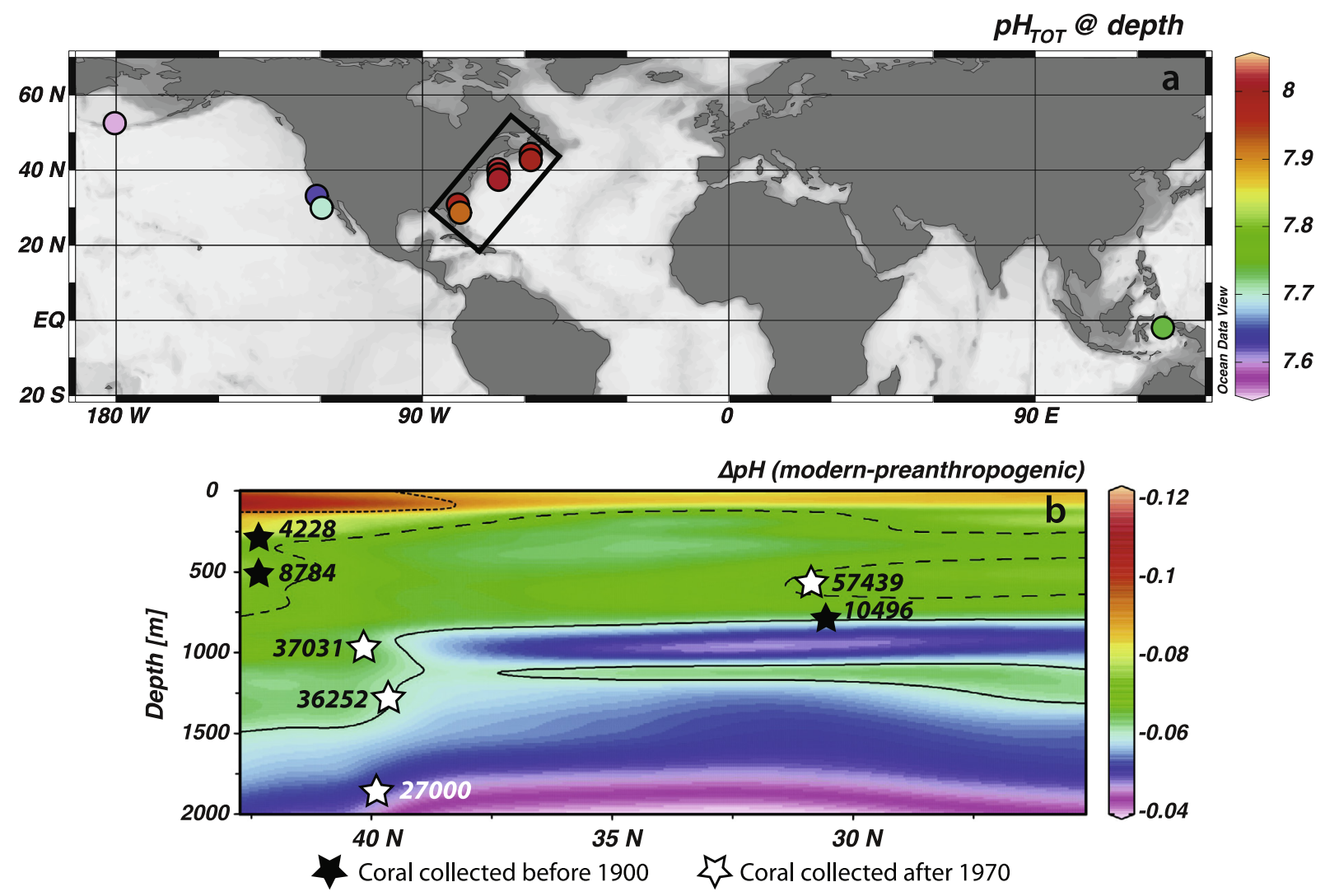

Fig. 2. (a) Ambient seawater pH (total scale, circle fill) at locations of Keratoisis corals in this study; black box denotes transect shown in (b). (b) Atlantic coral specimens (black and white stars) plotted with the expected change in seawater $\mathrm{pH}$ between the preindustrial and modern (gridded color) using anthropogenic DIC data from Sabine et al. (2004), temperature and salinity from World Ocean Atlas 2009 (Locarnini et al., 2010; Antonov et al., 2010), and assuming no change in alkalinity. Contours reflect the minimum resolvable pH change due to external analytical $\delta^{11} \mathrm{~B}$ error from three (dotted), five (dashed), and seven (solid) replicate analyses. Map and transect made using Ocean Data View (Schlitzer, 2014). (For interpretation of the references to color in this figure legend, the reader is referred to the web version of this article.)

the dissociation constant of boric acid $\left(p \mathrm{~K}_{\mathrm{B}}\right)$ a function of temperature, salinity (Dickson, 1990), and pressure (e.g., Millero, 1995). The boron isotope partitioning between boric acid and borate is described by an equilibrium fractionation factor $\left(\alpha_{\mathrm{B}}\right.$, also written as $\left.{ }^{11-10} K_{\mathrm{B}}\right)$ that has been experimentally determined in synthetic seawater at $25^{\circ} \mathrm{C}$, salinity of 35 and atmospheric pressure $\left(\alpha_{\mathrm{B}}=1.0272 \pm 0.0006\right.$, Klochko et al., 2006). Due to the lack of alternative experimental data, we assume that temperature, salinity and pressure do not influence the fractionation factor, and determine the isotopic composition of borate ion in seawater $\left(\delta^{11} \mathrm{~B}_{\text {borate }}\right)$ using the following equation:

$\delta^{11} \mathrm{~B}_{\text {borate }}(\%)=\frac{\delta^{11} \mathrm{~B}_{\mathrm{sw}} * \mathrm{~B}_{\mathrm{T}}-1000 *\left(\alpha_{\mathrm{B}}-1\right) *\left[\mathrm{~B}(\mathrm{OH})_{3}\right]}{\left[\mathrm{B}(\mathrm{OH})_{4}^{-}\right]+\alpha_{\mathrm{B}} *\left[\mathrm{~B}(\mathrm{OH})_{3}\right]}$

where $\delta^{11} \mathrm{~B}_{\mathrm{sw}}$ is the boron isotopic composition of seawater (39.61 $\pm 0.2 \%$ o [measurement 2sd], Foster et al., 2010), $\mathrm{B}_{\mathrm{T}}$ is the total boron concentration as a function of salinity (Lee et al., 2010), and $\left[\mathrm{B}(\mathrm{OH})_{3}\right]$ and $\left[\mathrm{B}(\mathrm{OH})_{4}^{-}\right]$are derived from $\mathrm{B}_{\mathrm{T}}, \mathrm{pH}$, and $p \mathrm{~K}_{\mathrm{B}}$. Uncertainty in $\delta^{11} \mathrm{~B}_{\text {borate was calculated }}$ by propagation of errors in $p \mathrm{~K}_{\mathrm{B}}$ from uncertainties in temperature, salinity, and coral collection depth (estimated as $\pm 100 \mathrm{~m}$ for specimens collected by trawl), along with $\mathrm{pH}$ error as calculated above. An additional error from uncertainty in anthropogenic carbon inventories calculated as $\pm 0.08 \%$ was added to $\delta^{11} \mathrm{~B}_{\text {borate }}$ uncertainty for the 19 th century corals. The resulting uncertainty in $\delta^{11} \mathrm{~B}_{\text {borate }}$ ranges from \pm 0.15 to $0.67 \%$, with the largest error for Specimen 1011762 from the Moluccan Sea, Indonesia, where proximal hydrographic data are unavailable (Table 1).

\subsection{Analytical procedures}

All isotopic data obtained in this study are provided in Table 2 and online through the Biological and Chemical Oceanography Data Management Office (http://www.bcodmo.org/project/542303). Forty to sixty microgram splits of drilled coral samples were analyzed for carbon and oxygen stable isotopes without chemical pretreatment or roasting (Grottoli et al., 2005). Samples were analyzed on a Thermo Delta V+ with dual inlet and Kiel IV device at the Lamont-Doherty Earth Observatory (LDEO), with values reported in per mil relative to the Vienna Pee-Dee Belemnite (VPDB). The $1 \sigma$ analytical accuracy for $\delta^{13} \mathrm{C}$ and $\delta^{18} \mathrm{O}$ based on replicate analyses of laboratory standards are $\pm 0.03 \%$ o 
Table 1

\begin{tabular}{|c|c|c|c|c|c|c|c|c|c|c|c|c|c|c|c|c|c|c|}
\hline \multirow{2}{*}{\multicolumn{2}{|c|}{$\begin{array}{l}\text { Sample ID L L } \\
\text { Specimen Data }\end{array}$}} & Location & Collection $^{\mathrm{a}}$ & \multicolumn{2}{|l|}{ Taxa } & \multicolumn{2}{|c|}{ Year Collected } & \multicolumn{2}{|c|}{ Diameter $(\mathrm{mm})$} & \multicolumn{2}{|c|}{ Depth (m) } & \multicolumn{2}{|c|}{ Lat $\left({ }^{\circ} \mathrm{N}\right)$} & Long $\left({ }^{\circ} \mathrm{E}\right)$ & \multicolumn{2}{|l|}{$[\mathrm{B}](\mathrm{ppm})$} & \multicolumn{2}{|c|}{$\mathrm{B} / \mathrm{Ca}(\mu \mathrm{mol} / \mathrm{mol})^{\mathrm{b}}$} \\
\hline & & & & \multirow{2}{*}{\multicolumn{2}{|c|}{ Keratoisis sp. }} & \multirow{2}{*}{\multicolumn{2}{|c|}{2001}} & \multirow{2}{*}{\multicolumn{2}{|c|}{14.5}} & \multirow{2}{*}{\multicolumn{2}{|c|}{$454-492$}} & \multirow{2}{*}{\multicolumn{2}{|c|}{52.479}} & \multirow[b]{2}{*}{179.692} & & \multirow{2}{*}{\multicolumn{3}{|c|}{75}} \\
\hline 1004643 & \multicolumn{2}{|c|}{ Bering Sea } & NMNH & & & & & & & & & & & & 8.1 & & & \\
\hline T664 A17 & \multicolumn{2}{|c|}{$\begin{array}{l}\text { California } \\
\text { Margin }\end{array}$} & T. Hill & \multicolumn{2}{|c|}{ Keratoisis sp. } & \multicolumn{2}{|l|}{2008} & \multicolumn{2}{|l|}{30} & \multicolumn{2}{|c|}{1295} & \multicolumn{2}{|l|}{33.130} & -120.910 & 11.6 & \multicolumn{3}{|c|}{107} \\
\hline 37031 & Bear & Seamount & YPM & Keratc & isis grayi & 2004 & & 13.2 & & $847-10$ & & 40.257 & & 7.691 & 9.4 & & 87 & \\
\hline T668 A13 & $\begin{array}{l}\text { Calif } \\
\text { Mar }\end{array}$ & $\begin{array}{l}\text { rnia } \\
\text { in }\end{array}$ & T. Hill & Keratc & isis sp. & 2004 & & 50 & & 2136 & & 31.910 & & 20.050 & 8.2 & & 76 & \\
\hline 36252 & Bear & Seamount & YPM & Keratc & isis sp. & 2002 & & 21.5 & & $1195-1$ & 402 & 39.883 & & 7.433 & 10.1 & & 94 & \\
\hline 27000 & Bear & Seamount & YPM & Keratc & isis grayi & 2000 & & 13 & & $1826-2$ & 008 & 39.912 & & 7.489 & 10.9 & & 101 & \\
\hline 57439 & East & Florida & NMNH & Keratc & isis $\mathrm{sp}$. & 1972 & & 35 & & 658 & & 30.870 & & 9.570 & 14.5 & & 134 & \\
\hline 10496 & East & Florida & NMNH & Keratc & isis grayi & 1886 & & 10.8 & & 805 & & 30.733 & & 9.433 & 10.0 & & 92 & \\
\hline 8784 & Scot & in Slope & YPM & Keratc & isis grayi & 1879 & & 8.8 & & 503 & & 44.250 & & 8.050 & 9.8 & & 91 & \\
\hline 4228 & Scot & an Slope & $\mathrm{NMNH}$ & Keratc & isis grayi & 1879 & & 9.5 & & 320 & & 44.220 & & 8.030 & 9.1 & & 84 & \\
\hline 1011762 & Mol & ccan Sea & NMNH & Kerate & isis sp. & Subf & ossil ${ }^{\mathrm{c}}$ & 81 & & 732 & & -1.892 & & .650 & 10.8 & & 100 & \\
\hline Specimen & Date & Station & Latitude & Longitude & $\begin{array}{l}\text { Depth } \\
(\mathrm{m})\end{array}$ & $\begin{array}{l}\mathrm{T} \\
\left({ }^{\circ} \mathrm{C}\right)\end{array}$ & Salinity & $\begin{array}{l}\text { Alk } \\
\left(\mu \mathrm{mol} \mathrm{kg}{ }^{-1}\right)\end{array}$ & $\begin{array}{l}\text { DIC } \\
(\mu \mathrm{m}\end{array}$ & $\left.\mathrm{ol} \mathrm{kg}^{-1}\right)$ & $\begin{array}{l}\mathrm{pH} \\
\text { (To }\end{array}$ & & $\Omega_{\text {calcite }} \mathrm{d}^{\mathrm{d}}$ & $p \mathrm{~K}_{\mathrm{B}}$ & $\delta^{11} \mathrm{~B}_{\text {borate }}$ & $\delta^{18} \mathrm{O}_{\mathrm{sw}}{ }^{\mathrm{e}}$ & $\begin{array}{l}\delta^{13} \mathrm{C} \\
\mathrm{DIC}\end{array}$ & $\begin{array}{l}\delta^{13} \mathrm{C} \\
\text { source }^{\mathrm{f}}\end{array}$ \\
\hline Hydrograp & hic Data & & & & & & & & & & & & & & & & & \\
\hline 1004643 & $\begin{array}{l}7 / 10 / \\
1993\end{array}$ & $\begin{array}{l}\text { WOCE } \\
\text { P14 N-17 }\end{array}$ & 51.86 & -179.79 & 453 & 3.45 & 34.06 & 2327 & 233 & & 7.58 & \pm 0.04 & 0.87 & 8.8444 & $13.47 \pm 0.18$ & -0.22 & -0.68 & $\begin{array}{l}\text { WOCE } \\
\text { P13 N-5 }\end{array}$ \\
\hline $\begin{array}{l}\text { T664 } \\
\text { A17 }\end{array}$ & $\begin{array}{l}2 / 9 / \\
1994\end{array}$ & $\begin{array}{l}\text { WOCE } \\
\text { P02-85 }\end{array}$ & 31.00 & -121.22 & 1245 & 3.3 & 34.53 & 2394 & 237 & & 7.63 & \pm 0.02 & 0.92 & 8.7994 & $13.82 \pm 0.15$ & -0.03 & -0.5 & $\begin{array}{l}\text { Kimball } \\
\text { et al. (2014) }\end{array}$ \\
\hline 37031 & $\begin{array}{l}9 / 2 / \\
1997\end{array}$ & $\begin{array}{l}\text { WOCE } \\
\text { A22-71 }\end{array}$ & 40.18 & -66.19 & 990 & 4.22 & 34.98 & 2309 & 216 & & 8.01 & \pm 0.01 & 2.10 & 8.8031 & $15.83 \pm 0.16$ & 0.28 & 0.93 & $\begin{array}{l}\text { Kroopnick- } \\
29\end{array}$ \\
\hline $\begin{array}{l}\text { T668 } \\
\text { A13 }\end{array}$ & $\begin{array}{l}2 / 9 / \\
1994\end{array}$ & $\begin{array}{l}\text { WOCE } \\
\text { P02-85 }\end{array}$ & 31.00 & -121.22 & 1997 & 2.08 & 34.64 & 2424 & 2378 & & 7.70 & \pm 0.05 & 0.92 & 8.7690 & $14.22 \pm 0.27$ & -0.01 & -0.6 & $\begin{array}{l}\text { Kimball } \\
\text { et al. (2014) }\end{array}$ \\
\hline 36252 & $\begin{array}{l}9 / 2 / \\
1997\end{array}$ & $\begin{array}{l}\text { WOCE } \\
\text { A22-71 }\end{array}$ & 40.18 & -66.19 & 1237 & 3.83 & 34.95 & 2310 & 215 & & 8.02 & \pm 0.01 & 2.04 & 8.7903 & $16.00 \pm 0.16$ & 0.28 & 0.87 & $\begin{array}{l}\text { Kroopnick- } \\
29\end{array}$ \\
\hline 27000 & $\begin{array}{l}9 / 2 / \\
1997\end{array}$ & $\begin{array}{l}\text { WOCE } \\
\text { A22-71 }\end{array}$ & 40.18 & -66.19 & 1879 & 3.33 & 34.93 & 2309 & 2156 & & 8.00 & \pm 0.01 & 1.78 & 8.7635 & $16.11 \pm 0.15$ & 0.27 & 0.92 & $\begin{array}{l}\text { Kroopnick- } \\
29\end{array}$ \\
\hline 57439 & $\begin{array}{l}4 / 11 / \\
1981\end{array}$ & $\begin{array}{l}\text { TTO- } \\
\text { TAS-13 }\end{array}$ & 29.93 & -77.35 & 692 & 13.22 & 35.74 & 2341 & 2142 & & 7.99 & \pm 0.06 & 2.99 & 8.7025 & $16.47 \pm 0.55$ & 0.54 & 0.78 & $\begin{array}{l}\text { Kroopnick- } \\
30\end{array}$ \\
\hline 10496 & $\begin{array}{l}4 / 11 / \\
1981\end{array}$ & $\begin{array}{l}\text { TTO- } \\
\text { TAS-13 }\end{array}$ & 29.93 & -77.35 & 790 & 10.88 & 35.41 & 2327 & 2172 & & 7.95 & \pm 0.08 & 2.37 & 8.7253 & $16.07 \pm 0.57$ & 0.42 & 0.71 & $\begin{array}{l}\text { Kroopnick- } \\
30\end{array}$ \\
\hline 8784 & $\begin{array}{l}10 / 15 / \\
1981\end{array}$ & $\begin{array}{l}\text { TTO- } \\
\text { NAS-246 }\end{array}$ & 42.76 & -59.41 & 496 & 4.88 & 34.93 & 2305 & 2168 & & 8.03 & \pm 0.02 & 2.23 & 8.8194 & $15.92 \pm 0.19$ & 0.21 & 0.69 & $\begin{array}{l}\text { Kroopnick- } \\
29\end{array}$ \\
\hline 4228 & $\begin{array}{l}10 / 16 / \\
1981\end{array}$ & $\begin{array}{l}\text { TTO- } \\
\text { NAS-249 }\end{array}$ & 43.01 & -59.59 & 240 & 7.19 & 34.91 & 2307 & 2179 & & 7.99 & \pm 0.05 & 2.26 & 8.7991 & $15.78 \pm 0.37$ & 0.44 & 1.37 & $\begin{array}{l}\text { Kroopnick- } \\
29\end{array}$ \\
\hline 1011762 & $\begin{array}{l}8 / 15 / \\
1994\end{array}$ & $\begin{array}{l}\text { WOCE } \\
\text { P09-97 }\end{array}$ & -1.00 & 142.02 & 598 & 6.64 & 34.54 & 2321 & 2217 & & 7.87 & \pm 0.10 & 1.84 & 8.7865 & $15.03 \pm 0.67$ & 0.05 & 0.52 & $\begin{array}{l}\text { WOCE } \\
\text { P10-16 }\end{array}$ \\
\hline
\end{tabular}

${ }^{a} \mathrm{NMNH}=$ Smithsonian National Museum of Natural History; YPM $=$ Yale Peabody Museum.

${ }^{\mathrm{b}}(\mathrm{B} / \mathrm{Ca})=[\mathrm{B}] /\left(\mathrm{mwB} * \mathrm{mwCaCO}_{3}\right)$.

c Radiocarbon age of $1690 \pm 25{ }^{14} \mathrm{C}$ years before 1950 .

d Calculated using CO2sys; Reported error is estimated $2 \sigma$ (see text)

LeGrande and Schmidt (2006).

${ }^{\mathrm{f}}$ Stations from Kroopnick (1980). 
Table 2

Boron, carbon, and oxygen isotopic data for coral specimens.

\begin{tabular}{|c|c|c|c|c|c|c|c|c|c|c|c|}
\hline Coral & Sample $^{\mathrm{a}}$ & $\begin{array}{l}\text { Depth } \\
\text { from distal } \\
\text { surface } \\
(\mathrm{mm})\end{array}$ & $\begin{array}{l}\text { Distance } \\
\text { from } \\
\text { center } \\
(\mathrm{mm})\end{array}$ & $\delta^{11} \mathrm{~B}^{\mathrm{b}}$ & $\begin{array}{l}\text { Measurement } \\
\text { 2SE }\end{array}$ & $\begin{array}{l}\text { External } \\
2 \mathrm{SE}^{\mathrm{c}}\end{array}$ & $n^{\mathrm{d}}$ & $\delta^{13} \mathrm{C}$ & $\delta^{18} \mathrm{O}$ & $\begin{array}{l}\delta^{13} \mathrm{C}(\text { coral- } \\
\text { water) }\end{array}$ & $\begin{array}{l}\delta^{18} \mathrm{O}(\text { coral- } \\
\text { water })\end{array}$ \\
\hline \multicolumn{12}{|l|}{ Pacific corals } \\
\hline \multirow[t]{21}{*}{ T668-A13 } & S-Average & 0.0 & 22.0 & 15.21 & 0.30 & 0.19 & 10 & -1.73 & 1.40 & -1.13 & 1.41 \\
\hline & S-1 & 0.0 & 22.0 & 14.80 & 0.16 & 0.26 & 5 & -1.46 & 1.43 & -0.86 & 1.44 \\
\hline & S-2 & 0.0 & 22.0 & 15.62 & 0.24 & 0.26 & 5 & -2.01 & 1.37 & -1.41 & 1.38 \\
\hline & D1 & 2.3 & 19.7 & 15.59 & 0.17 & 0.21 & 8 & -1.91 & 1.71 & -1.31 & 1.41 \\
\hline & D2 & 5.7 & 16.3 & 14.89 & 0.23 & 0.22 & 7 & -2.22 & 0.97 & -1.62 & 1.72 \\
\hline & D3 & 9.6 & 12.4 & 15.34 & 0.20 & 0.24 & 6 & -2.70 & 0.89 & -2.10 & 0.98 \\
\hline & D4 & 12.7 & 9.3 & 15.66 & 0.28 & 0.21 & 8 & -2.05 & 1.53 & -1.45 & 0.90 \\
\hline & D5 & 16.6 & 5.4 & 15.00 & 0.12 & 0.29 & 4 & -1.47 & 1.27 & -0.87 & 1.54 \\
\hline & D6 & 17.7 & 4.3 & 15.06 & 0.35 & 0.26 & 5 & -1.92 & 1.46 & -1.32 & 1.28 \\
\hline & D7 & 20.1 & 1.9 & 16.27 & 0.26 & 0.26 & 5 & -3.53 & 1.18 & -2.93 & 1.47 \\
\hline & MM1 & 2.5 & 19.5 & 15.34 & 0.47 & 0.34 & 3 & -1.85 & 1.44 & -1.25 & 1.45 \\
\hline & MM2 & 4.2 & 17.8 & & & & & -1.70 & 1.61 & -1.10 & 1.62 \\
\hline & MM3 & 7.4 & 14.6 & 14.63 & 0.02 & 0.34 & 3 & -1.99 & 1.53 & -1.39 & 1.54 \\
\hline & MM4 & 8.8 & 13.2 & & & & & -2.21 & 1.41 & -1.61 & 1.42 \\
\hline & MM5 & 13.2 & 8.8 & 14.85 & 0.28 & 0.42 & 2 & -1.84 & 1.37 & -1.24 & 1.38 \\
\hline & MM6 & 14.2 & 7.8 & 15.11 & 0.63 & 0.34 & 3 & -1.49 & 1.53 & -0.89 & 1.54 \\
\hline & MM7 & 16.3 & 5.7 & 15.09 & 0.08 & 0.34 & 3 & -1.85 & 1.32 & -1.25 & 1.33 \\
\hline & MM8 & 17.3 & 4.7 & 15.15 & 0.12 & 0.42 & 2 & -1.66 & 1.43 & -1.06 & 1.44 \\
\hline & MM9 & 18.5 & 3.5 & 14.77 & 0.12 & 0.29 & 4 & -1.81 & 1.80 & -1.21 & 1.81 \\
\hline & MM10 & 19.4 & 2.6 & 15.34 & 0.26 & 0.34 & 3 & -1.82 & 1.90 & -1.22 & 1.91 \\
\hline & MM11 & 20.2 & 1.8 & 16.10 & 0.23 & 0.22 & 7 & -2.10 & 1.81 & -1.50 & 1.82 \\
\hline \multirow[t]{6}{*}{ T664-A17 } & $\mathrm{S}$ & 0.0 & 9.9 & 14.92 & 0.20 & 0.22 & 7 & & & & \\
\hline & MM1 & 1.6 & 8.3 & 14.56 & 0.27 & 0.29 & 4 & -2.97 & 1.22 & -2.47 & 1.25 \\
\hline & MM2 & 3.0 & 6.9 & 14.69 & 0.28 & 0.29 & 4 & -1.37 & 1.71 & -0.87 & 1.74 \\
\hline & MM3 & 5.4 & 4.5 & 14.75 & 0.27 & 0.24 & 6 & -1.80 & 1.51 & -1.30 & 1.54 \\
\hline & MM4 & 7.0 & 2.9 & 15.10 & 0.36 & 0.29 & 4 & -1.99 & 1.46 & -1.49 & 1.49 \\
\hline & MM5 & 8.7 & 1.2 & 15.43 & 0.46 & 0.29 & 4 & -2.45 & 1.38 & -1.95 & 1.41 \\
\hline \multirow[t]{5}{*}{ USNM1004643 } & MM1 & 0.9 & 7.0 & 15.27 & 0.14 & 0.18 & 11 & -2.78 & 1.42 & -2.10 & 1.64 \\
\hline & MM2 & 1.7 & 6.2 & 15.33 & 0.41 & 0.26 & 5 & -5.43 & 0.53 & -4.75 & 0.75 \\
\hline & MM3 & 3.1 & 4.8 & 15.28 & 0.17 & 0.29 & 4 & -2.70 & 1.32 & -2.02 & 1.54 \\
\hline & MM4 & 5.7 & 2.2 & 15.17 & 0.10 & 0.34 & 3 & -3.63 & 0.97 & -2.95 & 1.19 \\
\hline & MM5 & 6.8 & 1.1 & 15.46 & 0.16 & 0.29 & 4 & -3.85 & 0.98 & -3.17 & 1.20 \\
\hline USNM1011762 & MM1 & 0.0 & 0.00 & 13.69 & 0.24 & 0.17 & 12 & -5.18 & -0.71 & -5.70 & -0.76 \\
\hline \multicolumn{12}{|c|}{ Modern Atlantic corals } \\
\hline \multirow[t]{6}{*}{ YPM27000B } & $\mathrm{S}$ & 0.0 & 7.0 & 16.52 & 0.18 & 0.24 & 6 & -0.53 & 1.73 & -1.45 & 1.46 \\
\hline & D1 & 1.3 & 5.7 & 16.20 & 0.22 & 0.24 & 6 & & & & \\
\hline & D5 & 2.3 & 4.7 & 16.32 & 0.22 & 0.29 & 4 & 0.79 & 2.28 & -0.13 & 2.01 \\
\hline & D2 & 2.7 & 4.3 & 16.07 & 0.11 & 0.24 & 6 & 0.73 & 1.79 & -0.19 & 1.52 \\
\hline & D3 & 1.0 & 6.0 & 16.06 & 0.27 & 0.22 & 7 & 1.15 & 2.09 & 0.23 & 1.82 \\
\hline & D4 & 6.0 & 1.0 & 17.20 & 0.28 & 0.26 & 5 & 1.01 & 1.91 & 0.09 & 1.64 \\
\hline \multirow[t]{7}{*}{ YPM37031B } & $\mathrm{S}$ & 0.0 & 7.8 & 15.73 & 0.13 & 0.29 & 4 & & & & \\
\hline & D1 & 1.1 & 6.7 & 16.47 & 0.25 & 0.26 & 5 & 0.04 & 2.33 & -0.89 & 2.05 \\
\hline & D2 & 2.5 & 5.3 & 15.80 & 0.24 & 0.24 & 6 & 0.90 & 2.60 & -0.03 & 2.32 \\
\hline & D3 & 3.7 & 4.1 & 15.72 & 0.51 & 0.34 & 3 & 2.10 & 2.69 & 1.17 & 2.41 \\
\hline & D4 & 4.9 & 2.9 & 14.84 & 0.28 & 0.21 & 8 & 2.21 & 2.25 & 1.28 & 1.97 \\
\hline & D5 & 6.3 & 1.5 & 15.32 & 0.17 & 0.26 & 5 & 1.82 & 2.92 & 0.89 & 2.64 \\
\hline & D6 & 7.6 & 0.2 & 17.01 & 0.29 & 0.29 & 4 & 1.47 & 2.51 & 0.54 & 2.23 \\
\hline \multirow[t]{5}{*}{ USNM36252 } & $\mathrm{S}$ & 1.8 & 10.9 & 15.65 & 0.39 & 0.29 & 4 & 0.81 & 2.04 & -0.06 & 1.76 \\
\hline & D2-A & 5.8 & 6.9 & 15.89 & 0.22 & 0.29 & 4 & 1.11 & 2.22 & 0.24 & 1.94 \\
\hline & D3 & 9.3 & 3.4 & 15.50 & 0.14 & 0.29 & 4 & 1.10 & 2.03 & 0.23 & 1.75 \\
\hline & D4 & 11.4 & 1.3 & 15.35 & 0.21 & 0.34 & 3 & 1.45 & 2.10 & 0.58 & 1.82 \\
\hline & D5 & 12.5 & 0.2 & 15.82 & 0.12 & 0.29 & 4 & 0.43 & 1.77 & -0.44 & 1.49 \\
\hline
\end{tabular}




\begin{tabular}{|c|c|c|c|c|c|c|c|c|c|c|c|}
\hline \multirow[t]{5}{*}{ USNM57439 } & MM1 & 0.6 & 7.4 & 16.34 & 0.08 & 0.34 & 3 & 0.32 & 1.56 & -0.46 & 1.02 \\
\hline & MM2 & 2.6 & 5.4 & & & & & 0.38 & 1.64 & -0.40 & 1.10 \\
\hline & MM3 & 4.2 & 3.8 & & & & & 0.50 & 1.61 & -0.28 & 1.07 \\
\hline & MM4 & 5.9 & 2.1 & 16.38 & 0.47 & 0.42 & 2 & -0.03 & 1.34 & -0.81 & 0.80 \\
\hline & MM5 & 7.0 & 1.0 & 17.26 & 0.14 & 0.34 & 3 & -0.34 & 1.25 & -1.12 & 0.71 \\
\hline \multicolumn{12}{|c|}{ Preindustrial Atlantic corals } \\
\hline \multirow[t]{3}{*}{ USNM4228 } & MM1 & 0.2 & 4.8 & 15.43 & 0.38 & 0.34 & 3 & 1.21 & 1.75 & -0.50 & 1.31 \\
\hline & MM2 & 2.6 & 2.4 & 15.85 & 0.10 & 0.34 & 3 & 0.58 & 1.85 & -1.13 & 1.41 \\
\hline & MM3 & 4.5 & 0.5 & 17.13 & 0.13 & 0.26 & 5 & 0.06 & 2.01 & -1.65 & 1.57 \\
\hline \multirow[t]{11}{*}{ USNM10496 } & S1/MM1 & 1.0 & 5.3 & 16.48 & 0.33 & 0.29 & 4 & -0.43 & 1.57 & -1.46 & 1.15 \\
\hline & $\mathrm{S} 2$ & 0.0 & 0.0 & 16.85 & 0.09 & 0.22 & 7 & -0.62 & 1.03 & -1.65 & 0.61 \\
\hline & S3 & 0.0 & 0.0 & 17.25 & 0.30 & 0.29 & 4 & -1.00 & 0.86 & -2.03 & 0.44 \\
\hline & S4 & 0.0 & 0.0 & 16.70 & 0.17 & 0.26 & 5 & -0.90 & 0.85 & -1.93 & 0.43 \\
\hline & S5 & 0.0 & 0.0 & 16.80 & 0.08 & 0.34 & 3 & -1.11 & 0.80 & -2.14 & 0.38 \\
\hline & S6 & 0.0 & 0.0 & 16.25 & 0.94 & 0.29 & 4 & -1.03 & 0.89 & -2.06 & 0.47 \\
\hline & S7 & 0.0 & 0.0 & 15.57 & 0.41 & 0.29 & 4 & -1.23 & 0.86 & -2.26 & 0.44 \\
\hline & S8 & 0.0 & 0.0 & 17.07 & 0.18 & 0.26 & 5 & -1.43 & 0.71 & -2.46 & 0.29 \\
\hline & MM2 & 1.7 & 4.6 & 17.21 & 0.13 & 0.42 & 2 & -0.84 & 1.38 & -1.87 & 0.96 \\
\hline & MM3 & 3.2 & 3.1 & 16.91 & 0.34 & 0.42 & 2 & -0.67 & 1.41 & -1.70 & 0.99 \\
\hline & MM4 & 5.1 & 1.2 & 16.94 & 0.13 & 0.26 & 5 & -1.26 & 1.06 & -2.29 & 0.64 \\
\hline \multirow[t]{4}{*}{ YPM8784 } & $\mathrm{S}$ & 1.0 & 3.0 & 16.02 & 0.19 & 0.24 & 6 & 1.43 & 1.58 & -0.03 & 1.37 \\
\hline & D2 & 2.0 & 2.0 & 15.89 & 0.21 & 0.26 & 5 & 1.58 & 1.76 & 0.12 & 1.55 \\
\hline & D3 & 3.0 & 1.0 & 16.08 & 0.23 & 0.24 & 6 & 1.87 & 1.83 & 0.41 & 1.62 \\
\hline & D4 & 3.8 & 0.2 & 16.46 & 0.33 & 0.24 & 6 & & & & \\
\hline
\end{tabular}

${ }^{\mathrm{a}} \mathrm{D}=$ diamond rotary drill; $\mathrm{MM}=$ micromill; $\mathrm{S}=$ outer surface sample (taken with rotary drill). Fig. $4 \mathrm{~b}$ plots the first listed data point for each coral (S or MM1).

${ }^{\mathrm{b}}$ Italicized values denote samples with $<3$ acceptable replicates.

${ }^{\mathrm{c}}$ Reported error (bold) is the larger of either twice the internal standard error or the external error (see text).

${ }^{\mathrm{d}}$ Number of repeat $\delta^{11} \mathrm{~B}$ analyses on a single sample solution.

and $\pm 0.06 \%$, respectively. When available, replicate analyses of individual coral samples were precise to within $\pm 0.05 \%$ for $\delta^{13} \mathrm{C}$ and $\pm 0.08 \%$ for $\delta^{18} \mathrm{O}(1 \sigma)$. Coral isotope ratios were corrected for seawater $\delta^{13} \mathrm{C}$ from cruise measurements (WOCE and GEOSECS, Table 1) and seawater $\delta^{18} \mathrm{O}$ from LeGrande and Schmidt (2006) to allow direct comparison of $\delta^{13} \mathrm{C}$ and $\delta^{18} \mathrm{O}$ ratios in corals from different oceanographic regions (Fig. 2; Hill et al., 2011).

For boron isotope analyses, 1-2 mg of calcite powder was cleaned of organic material with $1 \% \mathrm{H}_{2} \mathrm{O}_{2}$ buffered in $0.1 \mathrm{~N} \mathrm{NaOH}$ at $80^{\circ} \mathrm{C}$ for $20 \mathrm{~min}$, then rinsed five times with boron-free MilliQ water under ultrasonication. Recovery varied from $70 \%$ to $90 \%$, as fine-grained material was invariably lost to suspension during rinse steps. Cleaning experiments performed on a bulk coral sample with varying concentration of oxidizing agent showed no change in coral $\delta^{11} \mathrm{~B}$ over orders of magnitude changes in oxidant concentration (between $0.3 \%$ and $4.8 \% \mathrm{H}_{2} \mathrm{O}_{2}$ ), suggesting that all reactive organic matter was effectively removed from the samples by the standard cleaning procedure (Fig. A1). Cleaned coral powders were dissolved in $2 \mathrm{~N} \mathrm{HCl}$ immediately prior to analysis. A sufficient volume of analyte to obtain a minimum of $1 \mathrm{ng}$ of $\mathrm{B}$ (typically $1.5-2 \mu \mathrm{L}$ depending on sample B concentration) was loaded with $1.0 \mu \mathrm{L}$ of a boron-free seawater matrix solution onto degassed rhenium filaments. To minimize procedural blank, all sample preparation was done in a boron-free PTFE filtered laminar flow bench, and Fisher Optima ${ }^{\circledR}$ grade chemicals were used for all treatments.
Boron isotope ratios were measured on a Thermo Triton multicollector thermal ionization mass spectrometer at LDEO in negative-ion mode (NTIMS, Hemming and Hanson, 1994; see detailed methodology in Foster et al., 2013). Average electric potentials for ${ }^{11} \mathrm{BO}_{2}^{-}$ranged between 120 and $300 \mathrm{mV}$. Boron isotope ratios are reported in delta notation $\left(\delta^{11} \mathrm{~B}\right)$ relative to the NIST 951 boric acid standard reference material (Catanzaro et al., 1970). NIST 951 was measured alongside sample analyses for standardization both as boric acid and precipitated in vaterite (Foster et al., 2013). Mass $26\left({ }^{12} \mathrm{C}^{14} \mathrm{~N}^{-}\right)$was monitored immediately prior to analyses, to check for isobaric interference on ${ }^{10} \mathrm{BO}_{2}^{-}$from organic material (Hemming and Hanson, 1994). No samples were excluded based on this criterion, as mass 26 counts were below previously determined thresholds for organic matter contamination (Hemming and Hanson, 1994; Foster et al., 2013). Boron concentrations were determined in a representative sample for each coral by isotope dilution with 5 ppm NIST 952 boric acid reference material (Table 1; Hemming and Hanson, 1994). A minimum of three acceptable repeat analyses was required for each reported $\delta^{11} \mathrm{~B}$ value, where analyses with $>1 \%$ within-run fractionation were discarded. Although only two acceptable repeat analyses were obtained for five samples, these numbers are reported here because of their close correspondence with surrounding measurements (Table 2).

Uncertainty in $\delta^{11} \mathrm{~B}$ measurements is reported as the larger value of either twice the measurement standard error 
( $2 \mathrm{SE}=2 \sigma / \sqrt{ } n$, where $n$ is the number of repeat analyses on a single sample solution), or the external error, which is given as the 2SE on repeat analyses of an in-house standard of NIST 951 precipitated in vaterite (Table 2; see Foster et al., 2013 and Penman et al., 2013). The minimum resolvable $\mathrm{pH}$ change is a direct function of this analytical error, such that detection of a smaller $\mathrm{pH}$ change requires a greater number of repeat analyses (Fig. 2b). To demonstrate the reproducibility of these analyses, we produced full replicates of seven samples. $\delta^{11} \mathrm{~B}$ values for the seven replicates all agree within overlapping 2SE (Table A1 and Fig. A2).

\subsection{Expected isotopic variability from anthropogenic carbon addition}

The dissolution of $\mathrm{C}_{\mathrm{ant}}$ in seawater is expected to have a twofold effect on the geochemical composition of seawater. First, anthropogenic fossil fuel burning and deforestation add isotopically light carbon to the atmosphere, which lowers the $\delta^{13} \mathrm{C}$ of atmospheric $\mathrm{CO}_{2}$ and, when mixed into the ocean, $\delta^{13} \mathrm{C}$ of the oceanic DIC reservoir (the ${ }^{13} \mathrm{C}$ Suess effect; Keeling, 1979). Second, the addition of $\mathrm{C}_{\text {ant }}$ increases the size of the DIC reservoir, acidifying seawater and lowering $\delta^{11} \mathrm{~B}_{\text {borate }}$.

Provided that the temporal histories of these oceanic DIC concentration and isotope changes are quantitatively constrained, they can be useful metrics for testing whether our DSC isotopes track deep-sea chemical changes caused by $\mathrm{C}_{\mathrm{ant}}$ addition. The magnitude of anthropogenic depletion of seawater $\delta^{13} \mathrm{C}_{\mathrm{DIC}}$ reflects the concentration of $\mathrm{C}_{\mathrm{ant}}$, which is a function of time since the water mass was last in contact with the atmosphere and the processes that influenced DIC after that time (Körtzinger et al., 2003; Olsen and Ninnemann, 2010). The change in seawater $\delta^{13} C_{\text {DIC }}$ at the locations of the three modern corals is projected by scaling the $\mathrm{C}_{\mathrm{ant}}$ inventories from Khatiwala et al. (2009) by the $\delta^{13} \mathrm{C}_{\mathrm{DIC}}-\left[\mathrm{C}_{\mathrm{ant}}\right]$ relationship established by Körtzinger et al. (2003), which predicts a $\delta^{13} \mathrm{C}_{\text {DIC }}$ lowering of $0.024 \pm 0.003 \%$ per $\mu \mathrm{mol} / \mathrm{kg}$ increase in $\left[\mathrm{C}_{\text {ant }}\right]$ compared to preindustrial conditions. Preindustrial seawater $\delta^{13} \mathrm{C}_{\mathrm{DIC}}$ for the coral locations is estimated as $1.25 \pm 0.15 \%$, using the value for preindustrial Labrador Sea Water from Olsen and Ninnemann (2010). This value is chosen because the modern Atlantic coral collection locations correspond to neutral density surfaces and chlorofluorocarbon inventories attributed to Labrador Sea Water (Lebel et al., 2008). Uncertainty in the seawater $\delta^{13} \mathrm{C}_{\mathrm{DIC}}$ projection is estimated by propagation of preindustrial seawater $\delta^{13} \mathrm{C}_{\text {DIC }}$ uncertainty $( \pm 0.15 \%), \delta^{13} \mathrm{C}_{\text {DIC }}\left[\mathrm{C}_{\text {ant }}\right]$ relationship uncertainty $( \pm 0.003 \%)$, and uncertainty in $\mathrm{C}_{\text {ant }}$ inventories $( \pm 20 \%)$.

We quantify the temporal history of $\delta^{11} \mathrm{~B}_{\text {borate }}$ at the locations of the three modern North Atlantic corals in a similar fashion. $\mathrm{C}_{\text {ant }}$ inventories from Khatiwala et al. (2009) are converted to $\mathrm{pH}$ by assuming steady-state temperature, salinity, and alkalinity, and then converted to $\delta^{11}$ B $_{\text {borate }}$ using the Klochko et al. (2006) boron isotope fractionation. This approach predicts a -0.025 unit change in seawater-pH, and a $-0.19 \%$ change in $\delta^{11} \mathrm{~B}_{\text {borate, }}$, per $10 \mu \mathrm{mol} \mathrm{kg}{ }^{-1}$ increase in $\mathrm{C}_{\text {ant }}$ inventory. Total uncertainty in the $\delta^{11} \mathrm{~B}_{\text {borate }}$ projection is estimated by propagation of modern hydrographic $\delta^{11} \mathrm{~B}_{\text {borate }}$ errors (Table 1) and $\delta^{11}$ $\mathrm{B}_{\text {borate }}$ error resulting from $\mathrm{C}_{\mathrm{ant}}$ inventory uncertainty $( \pm 20 \%)$.

\section{RESULTS}

\subsection{Stable isotopes from a single Keratoisis specimen}

We measured isotopes on samples taken from the outermost $1 \mathrm{~mm}$ of calcite on eight discrete internodes of a preindustrial Atlantic bamboo coral specimen (Fig. 3). $\delta^{11} \mathrm{~B}$ from different internode surfaces varies from $15.6 \%$ to $17.3 \%$ (Fig. 3b), and generally overlaps $\delta^{11} \mathrm{~B}_{\text {borate }}$ established from hydrographic data $(16.07 \pm 0.57 \%$ oo within uncertainty. There is little evidence for a trend in $\delta^{11} \mathrm{~B}$ along the longitudinal growth direction, although $\delta^{11} \mathrm{~B}$ of the two most terminal internodes analyzed in this specimen (samples S3 and S8, Fig. 3b) are the highest observed values and both are significantly more positive than $\delta^{11} \mathrm{~B}_{\text {borate. The average }}$ $\delta^{11} \mathrm{~B}$ of the internode surfaces $(16.62 \pm 0.37 \%$ ) is higher than, although within uncertainty of, $\delta^{11} \mathrm{~B}_{\text {borate. }} \delta^{13} \mathrm{C}$ and $\delta^{18} \mathrm{O}$ show negative trends along the longitudinal growth direction, with $\delta^{13} \mathrm{C}$ declining by $1.0 \%$ and $\delta^{18} \mathrm{O}$ by $0.8 \%$ between the basal (S1) and apical (S8) internodes analyzed

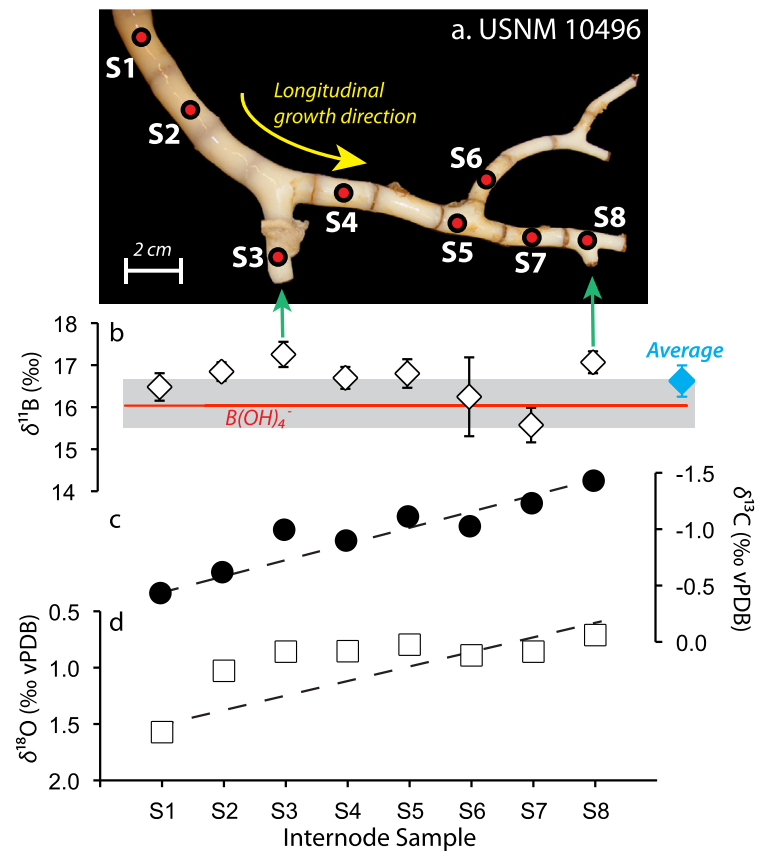

Fig. 3. (a) Location of samples taken for boron (b), carbon (c), and oxygen (d) isotopic composition of calcite from the distal skeleton of eight different internodes of a preindustrial North Atlantic bamboo coral specimen. Red line in (b) is the isotopic composition of borate ion in seawater (using $\alpha_{B}=1.0272$, Klochko et al., 2006) for the collection location of this specimen, with the gray shaded region denoting the uncertainty as described in the text. Blue diamond in (b) is the average of all surface internode measurements. Green arrows denote samples taken from terminal internodes of this specimen. (For interpretation of the references to color in this figure legend, the reader is referred to the web version of this article.) 

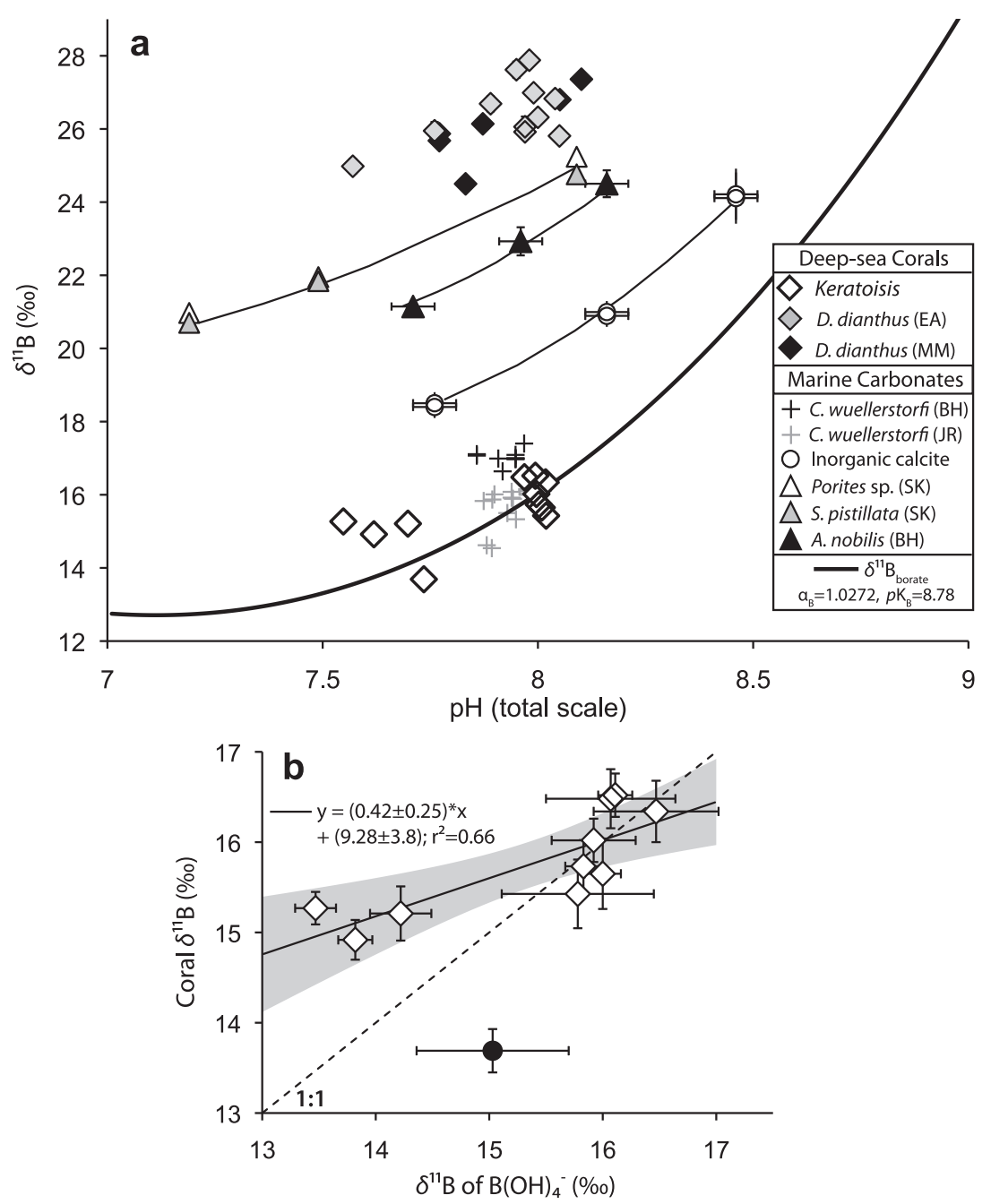

Fig. 4. (a) Keratoisis distal skeletal $\delta^{11} \mathrm{~B}$ versus hydrographic $\mathrm{pH}$. Also shown are the deep-sea scleractinian Desmophyllum dianthus (gray diamonds-EA, Anagnostou et al., 2012; black diamonds-MM, McCulloch et al., 2012), cultured shallow-water scleractinian corals (Acropora nobilis-BH, Hönisch et al., 2004; Stylophora pistillata and Porites sp.-SK, Krief et al., 2010), benthic foraminifer Cibicidoides wuellerstorfi (black +'s-BH, Hönisch et al., 2008; gray +'s-JR, Rae et al., 2011), and inorganic calcite (white circles, Sanyal et al., 2000). Solid curve shows the $\delta^{11} \mathrm{~B}$ of borate anion in seawater at representative deep-ocean $p \mathrm{~K}_{\mathrm{B}}=8.78$ (Dickson, 1990; Millero, 1995) as a function of $\mathrm{pH}$ based on the measured aqueous boron fractionation factor (Klochko et al., 2006). (b) Keratoisis surface $\delta^{11} \mathrm{~B}$ versus $\delta^{11} \mathrm{~B}$ of borate anion calculated for each coral collection location. Solid line is least-squares linear regression, with gray shading denoting $\pm 95 \%$ confidence intervals on the regression line. Dashed line is 1:1 line. Specimen 1011762 is indicated by the filled diamond and is excluded from the regression.

(Fig. $3 \mathrm{c}$ and $\mathrm{d}$ ). Considering that $\delta^{11} \mathrm{~B}$ does not appear to show systematic behavior (aside from possibly the terminal internodes), we chose the most basal (thickest) available internode of each specimen for comparison with hydrographic data and for creation of radial transects.

\subsection{Keratoisis boron isotope relationship with hydrographic data}

Samples drilled from the outermost $1 \mathrm{~mm}$ of calcite of the most basal internode in different Keratoisis specimens (hereafter referred to as "distal skeletal") exhibit boron isotopic compositions ranging from 13.7 to $16.5 \%$, with generally higher values $(>15.4 \%$ o $)$ for North Atlantic corals from locations above $\mathrm{pH}_{\text {tot }} 7.9$, and lower values (14.9-15.3\%) for Pacific corals from seawater $\mathrm{pH}_{\text {tot }}$ below 7.8 (Fig. 4). Specimen 1011762 from Indonesia shows a significantly lighter distal skeletal $\delta^{11} \mathrm{~B}(13.7 \%$ ) than all other analyzed corals, and is $1.3 \%$ lighter than $\delta^{11} \mathrm{~B}_{\text {borate }}$ calculated for its collection location. Considering the lack of proximal hydrographic data for this specimen and its pre-modern radiocarbon age $\left(1,690 \pm 25{ }^{14} \mathrm{C}\right.$ years $)$, we exclude this specimen from further statistical comparisons with modern corals.

Distal skeletal $\delta^{11} \mathrm{~B}$ positively and linearly correlates with corresponding $\delta^{11} \mathrm{~B}_{\text {borate }}$ values calculated from hydrographic data using the aqueous boron fractionation factor of Klochko et al. (2006) (Fig. 4b): 

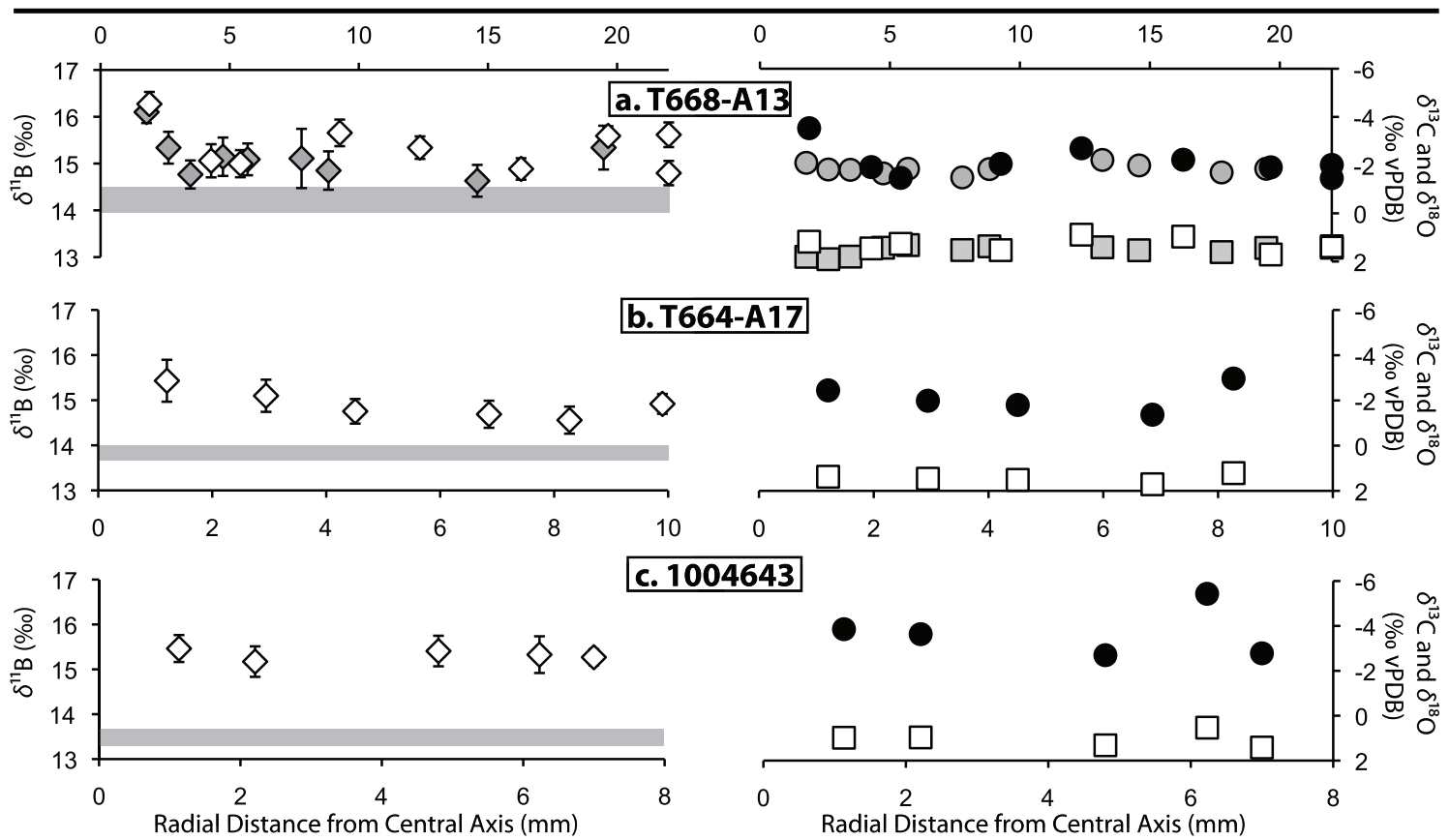

\section{$19^{\text {th }}$ Century Atlantic Corals}

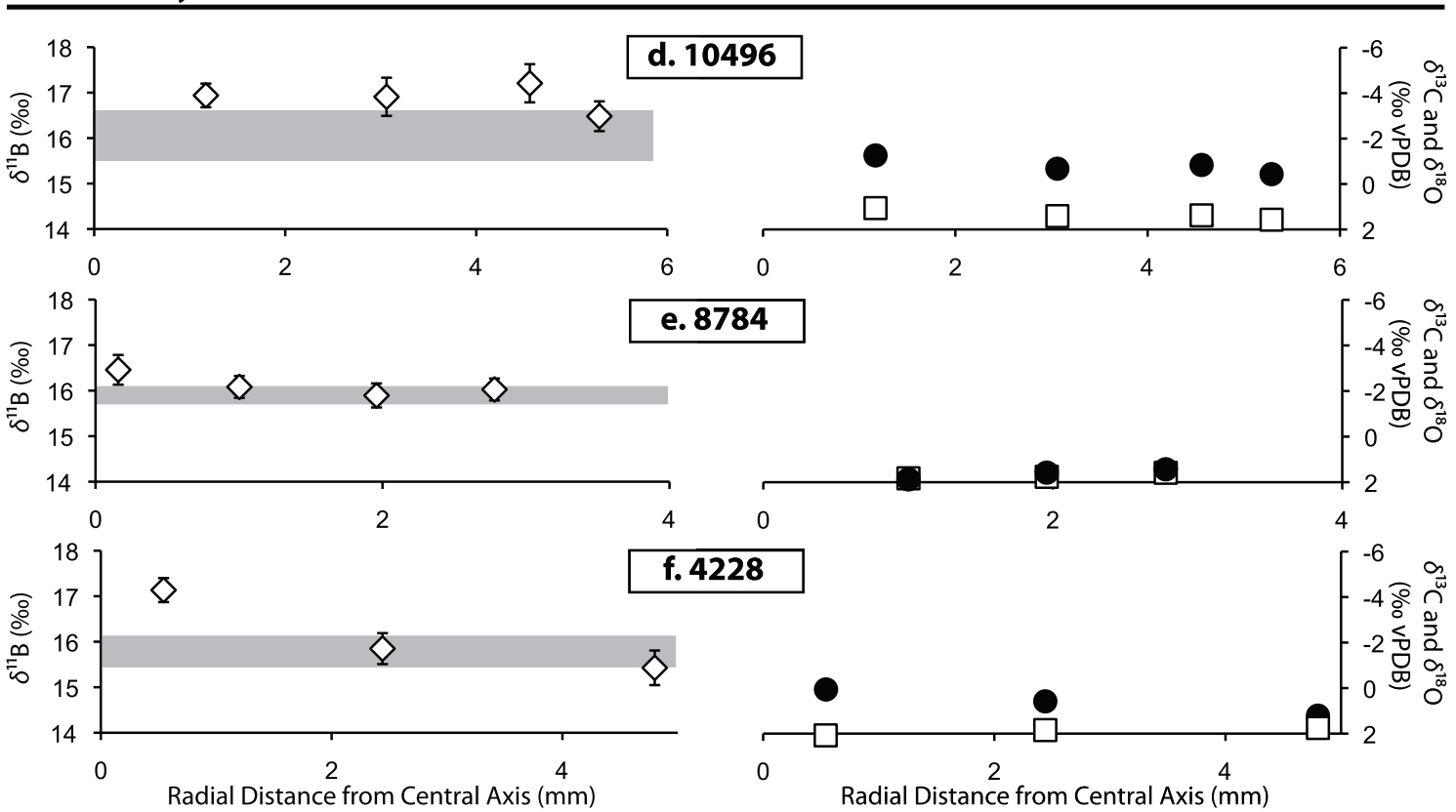

Fig. 5. Intracolony isotopic records from corals not exposed to anthropogenic carbon: (a-c) modern Pacific bamboo corals; (d-f) preindustrial Atlantic corals. Left side plots are $\delta^{11} \mathrm{~B}$ measurements with 2SE error bars (diamonds); right side plots are $\delta^{13} \mathrm{C}$ (black filled circles) and $\delta^{18} \mathrm{O}$ (open squares). All measurements are plotted against radial distance from the coral's central axis. Gray symbols in (a) are replicates from micromilling individual growth bands. Gray bars denote the range of $\delta^{11} \mathrm{~B}$ of borate ion in seawater at each collection location (using $\alpha_{\mathrm{B}}=1.0272$, Klochko et al., 2006, Table 1).

$$
\begin{aligned}
\delta^{11} \mathrm{~B}_{\text {coral }}(\%)= & (0.42 \pm 0.25) * \delta^{11} \mathrm{~B}_{\text {borate }} \\
& +(9.28 \pm 3.8) \quad\left(2 \mathrm{SE}, r^{2}=0.66\right)
\end{aligned}
$$

The slope of this relationship is significantly less than 1 (Student's $t$ test, $t(8)=14.5, p<0.001$ ) when all corals are included. This is mostly driven by Pacific $\delta^{11} \mathbf{B}_{\text {coral }}$ values, which are $1-2 \%$ higher than corresponding $\delta^{11} \mathrm{~B}_{\text {borate }}$ estimates (Fig. 4b). In contrast, Atlantic distal skeletal values are largely within error of a $1: 1 \quad \delta^{11} \mathrm{~B}_{\text {coral }}: \delta^{11} \mathrm{~B}_{\text {borate }}$ relationship, albeit across $\delta^{11} \mathrm{~B}_{\text {borate }}$ and $\mathrm{pH}$ ranges within overlapping error (15.78-16.47\% and 7.95-8.03 $\mathrm{pH}_{\mathrm{tot}}$; Table 1). 


\subsection{Radial isotope transects: Pacific and 19th Century Atlantic corals}

Fig. 5 displays $\delta^{11} \mathrm{~B}, \delta^{13} \mathrm{C}$ and $\delta^{18} \mathrm{O}$ transects (from the ontogenetically oldest calcite surrounding the central axis to the youngest, distal calcite) for modern bamboo corals from the Pacific Ocean and 19th century bamboo corals from the North Atlantic. These corals are unlikely to have experienced significant $\mathrm{C}_{\text {ant }}$ concentrations over their lifetimes, and therefore are assumed to have calcified under approximately steady-state conditions.

Pacific corals show $1-1.5 \%$ of $\delta^{11} \mathrm{~B}$ variability within single specimens (hereafter referred to as "intracolony") with no obvious trends (Fig. 5a-c). The three specimens exhibit similar absolute $\delta^{11} \mathrm{~B}$ values of $\sim 15-16 \%$, which are $0.5-2 \%$ higher than the calculated $\delta^{11} \mathrm{~B}_{\text {borate }}$ for each collection location (horizontal gray bars, Fig. 5a-c). Samples closest to the central axis generally give the highest intracolony $\delta^{11} \mathrm{~B}$ values, particularly for T668-A13 (Fig. 5a). $\delta^{18} \mathrm{O}$ and $\delta^{13} \mathrm{C}$ range from $+2 \%$ to $0 \%$ VPDB and $-2 \%$ to $-5.5 \%$ VPDB, respectively, with the most negative $\delta^{13} \mathrm{C}$ evident in Specimen 1004643 from the Bering Sea (Fig. 5c). There are no discernible trends in intracolony $\delta^{18} \mathrm{O}$ and $\delta^{13} \mathrm{C}$. For Specimen T668-A13, samples drilled using either a $1 \mathrm{~mm}$ dental drill (white and black symbols) or MicroMill with $0.5 \mathrm{~mm}$ bit (gray symbols) are largely comparable for $\delta^{11} \mathrm{~B}, \delta^{18} \mathrm{O}$ and $\delta^{13} \mathrm{C}$, suggesting that different sampling procedures (resolution) do not alter the isotopic measurements (Fig. 5a).

For the 19th century Atlantic corals (Fig. 5d-f), $\delta^{11}$ B values range from 15.5 to $17 \%$ and are similarly stable as Pacific corals, with a maximum of $1.5 \%$ variability in Specimen 4228 (Fig. 5f). $\delta^{11} \mathrm{~B}$ values are within error of or slightly elevated above calculated $\delta^{11} \mathrm{~B}_{\text {borate }}$ values. In two of the specimens, samples closest to the central axis show elevated $\delta^{11} \mathrm{~B}$ values compared to the rest of the coral (Fig. 5e, f). $\delta^{18} \mathrm{O}$ and $\delta^{13} \mathrm{C}$ are heavier than for Pacific corals, ranging from +2 to $+1 \%$ VPDB and 2 to $-2 \%$ VPDB, respectively.

\subsection{Radial isotope transects: modern Atlantic corals}

Fig. 6 compares $\delta^{11} \mathrm{~B}$ and $\delta^{13} \mathrm{C}$ records from three modern North Atlantic corals with calculated changes in $\delta^{11} \mathrm{~B}$ of seawater borate ion and $\delta^{13} \mathrm{C}$ of seawater DIC from $\mathrm{C}_{\mathrm{ant}}$ addition. We project a 0.28 to $0.36 \%$ decline in $\delta^{11} \mathrm{~B}_{\text {borate }}$ and a 0.47 to $0.57 \%$ decline in $\delta^{13} \mathrm{C}$ of seawater DIC over the lifespan of these corals due to $\mathrm{C}_{\mathrm{ant}}$ addition. Lending support to the robustness of these projections, the calculated temporal evolution of $\delta^{13} \mathrm{C}$ is in excellent agreement with $\delta^{13} \mathrm{C}$ measurements from the 1972-1973 GEOSECS cruises (Kroopnick, 1980) (Fig. 6).

Intracolony $\delta^{11} \mathrm{~B}$ and $\delta^{13} \mathrm{C}$ are noisier than the projections, with $1-2 \%$ of variability in both isotope systems exceeding the magnitudes of the expected $\mathrm{C}_{\mathrm{ant}}$ signals (Fig. 6). Coral $\delta^{11} \mathrm{~B}$ and $\delta^{13} \mathrm{C}$ values are similar to those observed in 19th century Atlantic corals (Fig. 5d-f), and generally consistent with the predicted data but too noisy to describe the projected trend. Similar to the Pacific and 19 th Century Atlantic corals, we observe elevated $\delta^{11} \mathrm{~B}$ values near the central axis for Specimens 27000 and 37031
(Fig. 6a and b). $\delta^{13} \mathrm{C}$ transects are within uncertainty of the projection for Specimen 27000 excluding the outermost sample (Fig. 6a) and for Specimen 36252 excluding the innermost sample (Fig. 6c).
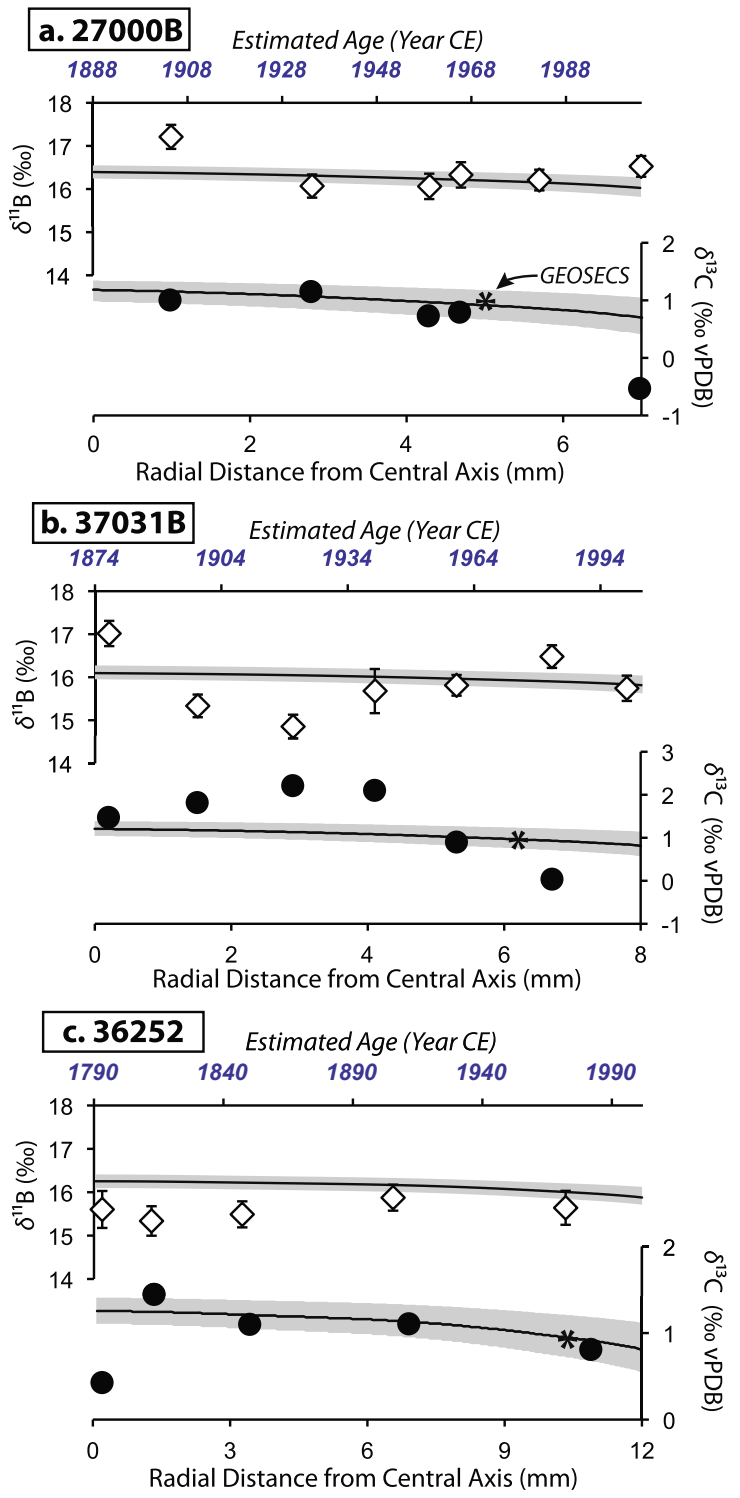

Fig. 6. Intracolony boron and carbon isotopic records from modern North Atlantic bamboo corals. Transects of bamboo coral $\delta^{11} \mathrm{~B}$ (diamonds, left) and $\delta^{13} \mathrm{C}$ (black circles, right) are plotted against radial distance from the coral's central axis as in Fig. 5. Timescales for the coral records are established by assuming coral radial growth rates of $60 \mu \mathrm{m} / \mathrm{year}$, consistent with previously published growth rates of Keratoisis specimens from the North Atlantic (Sherwood and Edinger, 2009). Black curves are projected temporal evolution of $\delta^{11} \mathrm{~B}_{\text {borate }}$ (using $\alpha_{\mathrm{B}}=1.0272$, Klochko et al., 2006) and $\delta^{13} \mathrm{C}$ of seawater DIC, respectively, with increasing seawater $\mathrm{C}_{\mathrm{ant}}$ at each coral collection location; gray shaded areas are propagated uncertainty in $\delta^{11} \mathrm{~B}_{\text {borate }}$ and $\delta^{13} \mathrm{C}$ of seawater DIC (see Section 2). Black asterisks are hydrographic seawater $\delta^{13} \mathrm{C}_{\text {DIC }}$ from GEOSECS data proximal to the coral collection locations and plotted relative to their collection time (Kroopnick, 1980; see Table 1). 


\subsection{Skeletal systematics of coral $\delta^{11} B$ variability}

$\delta^{11} \mathrm{~B}$ variability in Keratoisis specimens shows evidence for systematic offsets from $\delta^{11} \mathrm{~B}_{\text {borate }}\left(\Delta^{11} \mathrm{~B}=\delta^{11} \mathrm{~B}_{\text {coral }}\right.$ $-\delta^{11} \mathrm{~B}_{\text {borate }}$ ) both among and within specimens (Fig. 7a). Pacific corals, collected from locations with $\Omega_{\text {calcite }} 0.85$ 0.92 , show $+0.5-2 \% \Delta^{11} \mathrm{~B}$ values across the entire skeleton. Conversely, Atlantic corals collected from locations with $\Omega_{\text {calcite }} 1.7-2.3$ show $\Delta^{11} \mathrm{~B}$ ranging from approximately -1 to $+1.5 \%$. For all corals, $\delta^{11} \mathrm{~B}$ measurements proximal to the central axis are among the highest measured
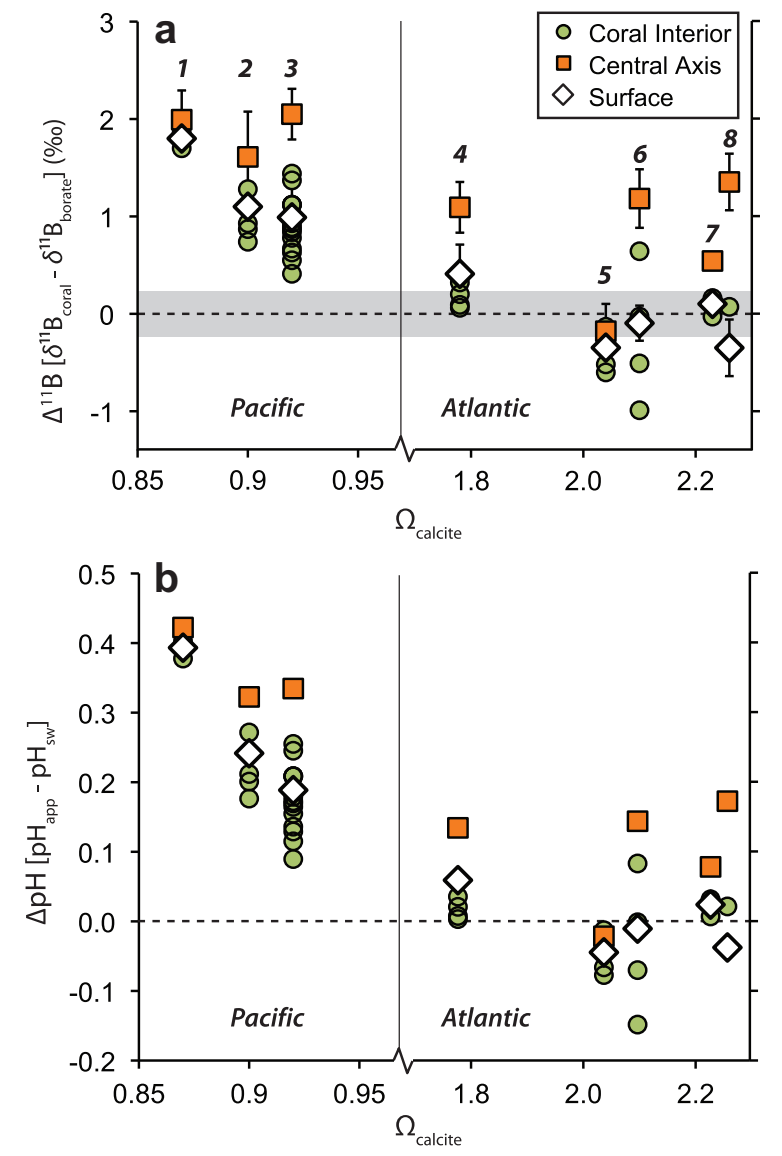

Fig. 7. (a) Difference between Keratoisis $\delta^{11} \mathrm{~B}$ measurements from eight modern specimens and $\delta^{11} \mathrm{~B}_{\text {borate }}$ (using $\alpha_{\mathrm{B}}=1.0272$, Klochko et al., 2006) from hydrographic data, plotted against $\Omega_{\text {calcite }}$ for the coral collection locations. Samples are grouped according to location within the coral internode: white diamonds indicate samples from the internode's distal skeleton (as shown in Fig. 4), green circles from the internode's radial thickening (error bars not shown), and orange squares from the internode's central axis (see Fig. 1d for example of different coral sampling regions). Shaded region represents average $\delta^{11} \mathrm{~B}_{\text {borate }}$ uncertainty $( \pm 0.27 \%$ ). Specimens are labeled from lowest to highest $\Omega_{\text {calcite }}: 1=1004643$, $2=$ T664-A17, $3=$ T668-A13, $4=27000,5=36252,6=37031$, $7=8784,8=4228$. (b) Difference between apparent coral $\mathrm{pH}$ calculated from coral $\delta^{11} \mathrm{~B}$ and seawater $\mathrm{pH}$. Note that Specimens 2 and 3 (T664-A17 and T668-A13) share the same collection $\Omega_{\text {calcite }}=0.92$ and are plotted with an $\Omega$ offset for clarity in (a) and (b). (For interpretation of the references to color in this figure legend, the reader is referred to the web version of this article.) intracolony $\delta^{11} \mathrm{~B}$ values, elevated by $\sim 2 \%$ above $\delta^{11} \mathrm{~B}_{\text {borate }}$ for Pacific specimens and by $0-1.5 \%$ above $\delta^{11} \mathrm{~B}_{\text {borate }}$ for Atlantic specimens. Outer surfaces of Atlantic specimens are within error of $\delta^{11} B_{\text {borate, }}$, while Pacific specimens are elevated, as noted earlier (Figs. 4 and 5).

\subsection{Quantifying stable isotope relationships}

Measured $\delta^{18} \mathrm{O}$ and $\delta^{13} \mathrm{C}$, corrected for local seawater$\delta^{18} \mathrm{O}$ and $-\delta^{13} \mathrm{C}_{\text {DIC }}$ (Table 1 ) and expressed as $\Delta^{18} \mathrm{O}$ and $\Delta^{13} \mathrm{C}$, respectively, generally positively correlate within individual corals (Fig. 8). Least-squares linear regressions return significant correlations (at 95\% confidence, $p<0.05$ ) for four specimens, and when grouping individual coral data from three North Atlantic specimens collected across a $<1{ }^{\circ} \mathrm{C}$ temperature range (Table 3 ). For the significant relationships, $\Delta^{18} \mathrm{O} / \Delta^{13} \mathrm{C}$ range from 0.24 to 0.61 , with intercept values $\left(\Delta^{18} \mathrm{O}=1.14-2.19 \%\right.$ at $\Delta^{13} \mathrm{C}=0 \%$ ) generally decreasing with increasing coral collection temperature.

Keratoisis $\delta^{11} \mathrm{~B}$ does not exhibit significant linear relationships with either $\delta^{18} \mathrm{O}\left(r^{2}=0.02, p=0.13\right)$ or $\delta^{13} \mathrm{C}$ $\left(r^{2}=0.01, p=0.26\right)$ from the same samples at the $95 \%$ confidence level (not visualized, but data are listed in Table 2).

\section{DISCUSSION}

\subsection{Response to anthropogenic carbon addition}

At the collection depths of the three modern North Atlantic corals, the projected magnitude of $\delta^{11} \mathrm{~B}_{\text {borate }}$ decline due to $\mathrm{C}_{\text {ant }}$ addition $(-0.28$ to $-0.36 \%$ ) is small relative to the uncertainty in modern $\delta^{11} \mathrm{~B}_{\text {borate }}( \pm 0.15$ $0.16 \%$ per site, Table 1) and analytical error (Table 2). Similarly, errors in $\delta^{13} C_{\text {DIC }}$ projections $( \pm 0.25-0.3 \%)$ are large relative to the magnitude of the projected $\delta^{13} \mathrm{C}_{\text {DIC }}$ decline $(-0.47$ to $-0.57 \%$ ). As a result, we cannot identify $\mathrm{C}_{\mathrm{ant}}$-forced $\delta^{11} \mathrm{~B}$ and $\delta^{13} \mathrm{C}$ trends in the isotopic composition of these corals with confidence.

Nevertheless, the comparison between coral $\delta^{11} \mathrm{~B}$ and $\delta^{13} \mathrm{C}$ and the projections is instructive. All three modern North Atlantic corals show intracolony $\delta^{11} \mathrm{~B}$ and $\delta^{13} \mathrm{C}$ variability that exceeds the range of expected changes from $\mathrm{C}_{\text {ant }}$ addition (Fig. 6). If the corals studied here record only changes in seawater chemistry, we would expect the intracolony $\delta^{11} \mathrm{~B}$ and $\delta^{13} \mathrm{C}$ records to match changes in $\delta^{11} \mathrm{~B}_{\text {borate }}$ and $\delta^{13} \mathrm{C}_{\text {DIC }}$ from increasing $\mathrm{C}_{\text {ant }}$ inventories. There is of course uncertainty in both the timing and magnitude of $\mathrm{C}_{\text {ant }}$ addition to the ocean and our coral growth rate estimates. However, we observe similar magnitudes of intracolony $\delta^{11} \mathrm{~B}$ and $\delta^{13} \mathrm{C}$ variability in Pacific corals, 19th century Atlantic corals (Fig. 5), and in multiple internode surfaces from a single 19th century Atlantic coral (Fig. 3), even though these specimens have encountered negligible anthropogenic DIC addition over their lifetimes. We therefore conclude that at least part of the $\delta^{11} \mathrm{~B}$ and $\delta^{13} \mathrm{C}$ variability observed in modern Atlantic bamboo corals is not related to changes in deep-sea $\mathrm{pH}$ and $\delta^{13} \mathrm{C}_{\text {DIC }}$ caused by $\mathrm{C}_{\mathrm{ant}}$ addition. 


\subsection{Comparison with $\delta^{11} B$ of other marine carbonates}

Modern and 19th century Keratoisis $\delta^{11} \mathrm{~B}$ values range between 14.5 and $17.3 \%$ (Fig. 4, Table 2), which are 6 to $13 \%$ lighter than bulk $\delta^{11} \mathrm{~B}$ measurements on the scleractinian deep-sea corals Desmophyllum dianthus (23.5$28.1 \%$, Anagnostou et al., 2012; 25.7-27.4\%, McCulloch et al., 2012; see Fig. 4a) and Lophelia pertusa (26.6$28.7 \%$, McCulloch et al., 2012), and are $>10 \%$ lighter than ion microprobe $\delta^{11} \mathrm{~B}$ analyses of a single L. pertusa specimen (28-38\%, Blamart et al., 2007). Similar offsets are observed between Keratoisis $\delta^{11} \mathrm{~B}$ values and the $\delta^{11} \mathrm{~B}$ of cultured shallow-water scleractinian corals at comparable pH values (genus Acropora, Hönisch et al., 2004; Reynaud et al., 2004; Porites and Stylophora pistillata, Krief et al., 2010) (Fig. 4a). In contrast, Keratoisis $\delta^{11}$ B values are more comparable to coretop measurements of the calcitic benthic foraminifer Cibicidoides wuellerstorfi (16.6-17.4\%o, Hönisch et al., 2008; 14.5-16.3\%o, Rae et al., 2011) (Fig. 4a).

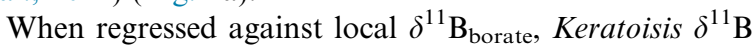
values return a linear relationship with a slope significantly shallower than one (Fig. 4b). This result is consistent with observations on corals, foraminifera and synthetic calcite grown over a wide pH range (Sanyal et al., 1996, 2000, 2001; Hönisch et al., 2004; Krief et al., 2010; Henehan et al., 2013), which tend to exhibit $\delta^{11} \mathbf{B}_{\text {carbonate versus }}$ $\delta^{11} \mathrm{~B}_{\text {borate }}$ regressions with a slope $<1$ (Table 4). Earlier studies had suggested this might be an artifact of boron isotope analyses by NTIMS versus MC-ICP-MS (Foster, 2008), but recent MC-ICP-MS studies of corals (Krief et al., 2010) and planktic foraminifers (Henehan et al., 2013) cultured over a wide $\mathrm{pH}$ range have confirmed the lower $\mathrm{pH}$ sensitivity of boron isotopes in these marine carbonates

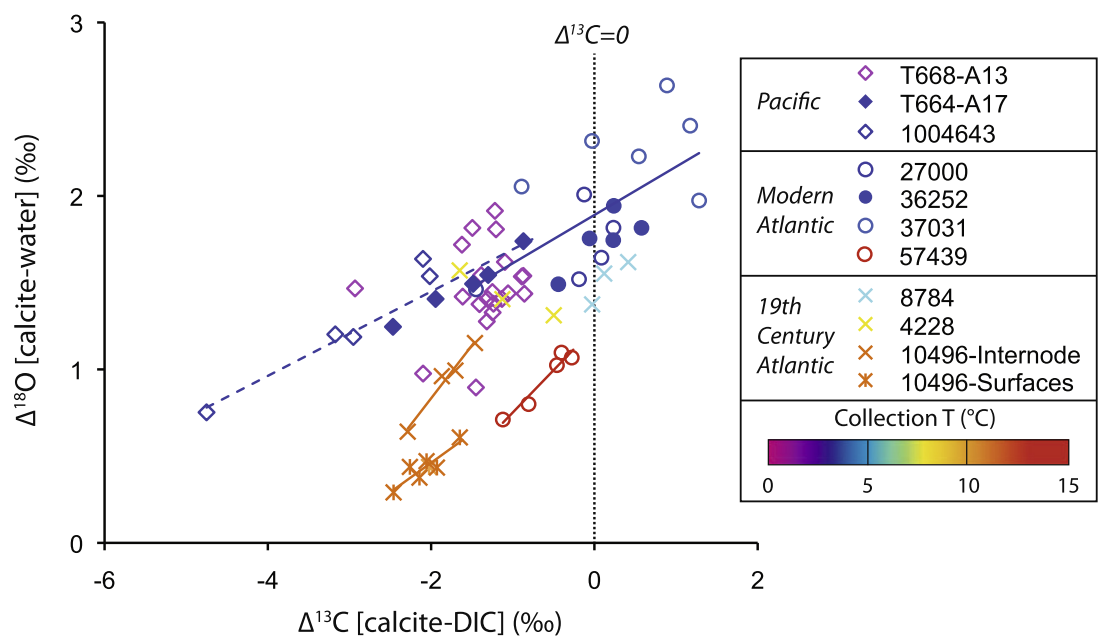

Fig. 8. $\Delta^{13} \mathrm{C}\left(\delta^{13} \mathrm{C}_{\text {calcite }}-\delta^{13} \mathrm{C}_{\text {DIC }}\right)$ versus $\Delta^{18} \mathrm{O}\left(\delta^{18} \mathrm{O}_{\text {calcite }}-\delta^{18} \mathrm{O}_{\text {water }}\right)$ for bamboo corals in this study. Circles indicate modern Atlantic corals (collected after 1970), crosses indicate 19th century Atlantic corals, and diamonds indicate Pacific corals. Symbol color corresponds to collection temperature for each coral. Filled symbols differentiate corals collected from similar temperatures in the same basin. Lines show significant $(p<0.05)$ linear regressions of $\Delta^{13} \mathrm{C}$ versus $\Delta^{18} \mathrm{O}$ (Table 3); dashed blue line includes data from T664-A17 and 1004643 , while solid blue line includes data from 27000,36252 and $37031 . \Delta^{13} \mathrm{C}=0$ is marked by a dotted line. (For interpretation of the references to color in this figure legend, the reader is referred to the web version of this article.)

Table 3

Regression parameters for $\Delta^{18} \mathrm{O}=m^{*} \Delta^{13} \mathrm{C}+b$. Bold values indicate regressions significant at $95 \%$ confidence.

\begin{tabular}{|c|c|c|c|c|c|c|c|c|}
\hline Specimen (s) & Collection $(\mathrm{T})$ & $m$ & 2SE & $b$ & $2 \mathrm{SE}$ & $r^{2}$ & $p$ & $n$ \\
\hline T668-A13 & 2.1 & 0.11 & 0.24 & 1.61 & 0.34 & 0.04 & 0.37 & 21 \\
\hline T664-A17 & 3.3 & 0.29 & 0.06 & 1.96 & 0.10 & 0.97 & 0.002 & 5 \\
\hline 1004643 & 3.5 & 0.31 & 0.07 & 2.19 & 0.22 & 0.96 & 0.003 & 5 \\
\hline T664-A17 and 1004643 & $3.3-3.5$ & 0.24 & 0.06 & 1.93 & 0.15 & 0.89 & $<0.001$ & 10 \\
\hline 27000 & 3.3 & 0.19 & 0.31 & 1.74 & 0.20 & 0.34 & 0.30 & 5 \\
\hline 36252 & 3.8 & 0.34 & 0.32 & 1.71 & 0.11 & 0.61 & 0.12 & 5 \\
\hline 37031 & 4.2 & 0.08 & 0.28 & 2.23 & 0.25 & 0.08 & 0.60 & 6 \\
\hline 27000,36252 and 37031 & $3.3-4.2$ & 0.27 & 0.20 & 1.89 & 0.14 & 0.33 & 0.02 & 16 \\
\hline 8784 & 4.9 & 0.51 & 0.47 & 1.43 & 0.12 & 0.81 & 0.29 & 3 \\
\hline 4228 & 7.2 & -0.22 & 0.10 & 1.19 & 0.12 & 0.96 & 0.14 & 3 \\
\hline 10496 (multiple surfaces) & 10.9 & 0.34 & 0.14 & 1.14 & 0.30 & 0.82 & 0.005 & 7 \\
\hline 10496 (single internode) & 10.9 & 0.61 & 0.13 & 2.05 & 0.24 & 0.98 & 0.01 & 4 \\
\hline 57439 & 13.2 & 0.49 & 0.14 & 1.24 & 0.10 & 0.94 & 0.006 & 5 \\
\hline
\end{tabular}


compared to boron in seawater. The slope of the $\delta^{11} \mathbf{B}_{\text {carbon- }}$ ate versus $\delta^{11} \mathrm{~B}_{\text {borate }}$ relationship for Keratoisis is lower in absolute magnitude, and in several cases, significantly lower than slopes observed in other samples (Table 4).

\subsection{Enumeration of vital effects in Keratoisis}

A long history of literature shows that biomineralization processes of marine calcifiers occur outside of thermodynamic equilibrium, with consequences for the geochemical composition and isotopic ratios of the resultant biominerals (e.g., Emiliani et al., 1978; McConnaughey, 1989; Smith et al., 2000; Cohen and McConnaughey, 2003; Allemand et al., 2011 and references therein). The biogeographic distribution of bamboo corals suggests they are no exception. Three bamboo corals in this study collected from the Pacific Ocean are from $\Omega_{\text {calcite }}<1$ (Table 1), and bamboo corals on the Tasmanian seamounts have been observed growing in similarly undersaturated conditions (Thresher et al., 2011). Since skeletal growth under equilibrium conditions would not be possible for these specimens, bamboo corals presumably possess an ability to manipulate seawater chemistry in order to calcify. As such, vital effects related to bamboo coral ontogeny likely affect the isotopic composition of Keratoisis.

One line of evidence supporting the presence of vital effects in Keratoisis is the positive correlation between $\delta^{13} \mathrm{C}$ and $\delta^{18} \mathrm{O}$ (Fig. 8). This correlation has previously been observed in bamboo corals and interpreted for paleotemperature reconstructions using the "lines method" (Hill et al., 2011; Kimball et al., 2014). Similar $\delta^{13} \mathrm{C}$ versus $\delta^{18} \mathrm{O}$ correlations are also observed at varying spatial scales in azooxanthellate scleractinian corals (Emiliani et al., 1978; McConnaughey, 1989; Smith et al., 2000; Adkins et al., 2003; Rollion-Bard et al., 2003a; Lutringer et al., 2005; López Correa et al., 2010). Positive correlations between $\delta^{13} \mathrm{C}$ and $\delta^{18} \mathrm{O}$ in biogenic carbonates have been attributed to kinetic isotope effects during calcification associated with the hydration and hydroxylation of $\mathrm{CO}_{2}$, and/or isotopic effects from changing $\mathrm{pH}$ in the calcifying fluid (McConnaughey, 1989; Adkins et al., 2003; Cohen and McConnaughey, 2003; Rollion-Bard et al., 2003a,b;
Zeebe, 2014). Therefore, the positive correlation between $\delta^{13} \mathrm{C}$ and $\delta^{18} \mathrm{O}$ in Keratoisis indicates that calcification processes influence the geochemistry of bamboo coral skeletons. The range of significant $\delta^{13} \mathrm{C}$ versus $\delta^{18} \mathrm{O}$ slopes observed here ( $m=0.24-0.61$, Fig. 8 and Table 3$)$ is consistent with those previously observed in bamboo coral ( $m=0.18-0.47$, Hill et al., 2011; $m=0.28-0.51$, Kimball et al., 2014) and scleractinian coral specimens $(m=0.23$ 0.67 , Smith et al., 2000; $m=0.34-0.53$, Adkins et al., 2003; $m=0.34-0.44$, Lutringer et al., 2005).

For quantification of vital effects, the boron isotopic composition of scleractinian corals has been hypothesized to record calcifying microenvironment $\mathrm{pH}$, with the difference (referred to as $\Delta \mathrm{pH}$ ) between calcifying microenvironment $\mathrm{pH}$ (i.e. $\delta^{11} \mathrm{~B}_{\text {coral }}$ ) and ambient seawater $\mathrm{pH}$ (i.e. $\delta^{11} \mathrm{~B}_{\text {borate }}$ ) reflecting the magnitude of $\mathrm{pH}$ vital effects during calcification (Rollion-Bard et al., 2003b, 2011; Blamart et al., 2007; Allison et al., 2010; Krief et al., 2010; Trotter et al., 2011; Anagnostou et al., 2012; McCulloch et al., 2012). Assuming only the borate anion is incorporated during coral calcification, the apparent $\mathrm{pH}$ of the calcifying fluid $\left(\mathrm{pH}_{\mathrm{app}}\right)$ can be inferred from coral $\delta^{11} \mathrm{~B}$ :

$$
\begin{aligned}
\mathrm{pH}_{\mathrm{app}}= & p \mathrm{~K}_{\mathrm{B}} \\
& -\log \left[\frac{\delta^{11} \mathrm{~B}_{\mathrm{sw}}-\delta^{11} \mathrm{~B}_{\text {coral }}}{\delta^{11} \mathrm{~B}_{\mathrm{sw}}-\left(\alpha_{\mathrm{B}} * \delta^{11} \mathrm{~B}_{\text {coral }}\right)-1000 *\left(\alpha_{\mathrm{B}}-1\right)}\right]
\end{aligned}
$$

where $p \mathrm{~K}_{\mathrm{B}}$ is determined for each coral collection location, $\delta^{11} \mathrm{~B}_{\mathrm{sw}}$ is the boron isotopic composition of seawater $\left(39.61 \%\right.$, Foster et al., 2010) and $\alpha_{\mathrm{B}}$ is the aqueous boron isotope fractionation factor (1.0272, Klochko et al., 2006). Using Eq. (3), elevation of boron isotope ratios in scleractinian corals above $\delta^{11} \mathrm{~B}_{\text {borate }}$ (Fig. 4a) implies a $\sim 0.4-1.2$ $\mathrm{pH}$ unit elevation in the calcifying fluid (Krief et al., 2010; Rollion-Bard et al., 2011; Trotter et al., 2011; Anagnostou et al., 2012; McCulloch et al., 2012) that is broadly consistent with in situ observations in shallow water scleractinians (Al-Horani et al., 2003; Venn et al., 2011, 2013).

Table 4

\begin{tabular}{|c|c|c|c|c|c|}
\hline Specimen Type & Taxa & $m^{\mathrm{a}}$ & $2 \mathrm{SE}$ & pH Range & Reference \\
\hline \multicolumn{6}{|l|}{ Natural Samples } \\
\hline Gorgonian Coral & Keratoisis & 0.42 & 0.25 & $7.58-8.03$ & This study \\
\hline Scleractinian Coral & D. dianthus & 0.75 & 0.56 & $7.58-8.05$ & Anagnostou et al. (2012) \\
\hline Benthic Foram & C. wuellerstorfi & 1.29 & 0.3 & $7.89-8.03$ & Rae et al. (2011) \\
\hline Planktonic Foram & N. pachyderma & 1.16 & 0.84 (1SE) & $7.7-7.9$ & Yu et al. (2013) \\
\hline \multicolumn{6}{|l|}{ Laboratory samples } \\
\hline Scleractinian Coral & Acropora & 0.76 & 0.1 & $7.71-8.16$ & Hönisch et al. (2004) \\
\hline Scleractinian Coral & Porites & 0.74 & 0.08 & $7.19-8.09$ & Krief et al. (2010) \\
\hline Scleractinian Coral & S. pistillata & 0.69 & 0.15 & $7.19-8.09$ & Krief et al. (2010) \\
\hline Planktonic Foram & G. ruber & 0.6 & 0.08 & $7.55-8.17$ & Henehan et al. (2013) \\
\hline Planktonic Foram & O. universa & 0.82 & 0.32 & $7.7-9.0$ & Sanyal et al. (1996) \\
\hline Planktonic Foram & G. sacculifer & 0.85 & 0.19 & $7.6-8.6$ & Sanyal et al. (2001) \\
\hline Synthetic Calcite & - & 0.75 & 0.15 & $7.9-8.6$ & Sanyal et al. (2000) \\
\hline
\end{tabular}

Regression parameters for $\delta^{11} \mathrm{~B}$ borate versus $\delta^{11} \mathrm{~B}$ carbonate.

${ }^{\text {a }}$ Slope of $\delta^{11} \mathrm{~B}$ borate versus $\delta^{11} \mathrm{~B}$ carbonate regression line. 

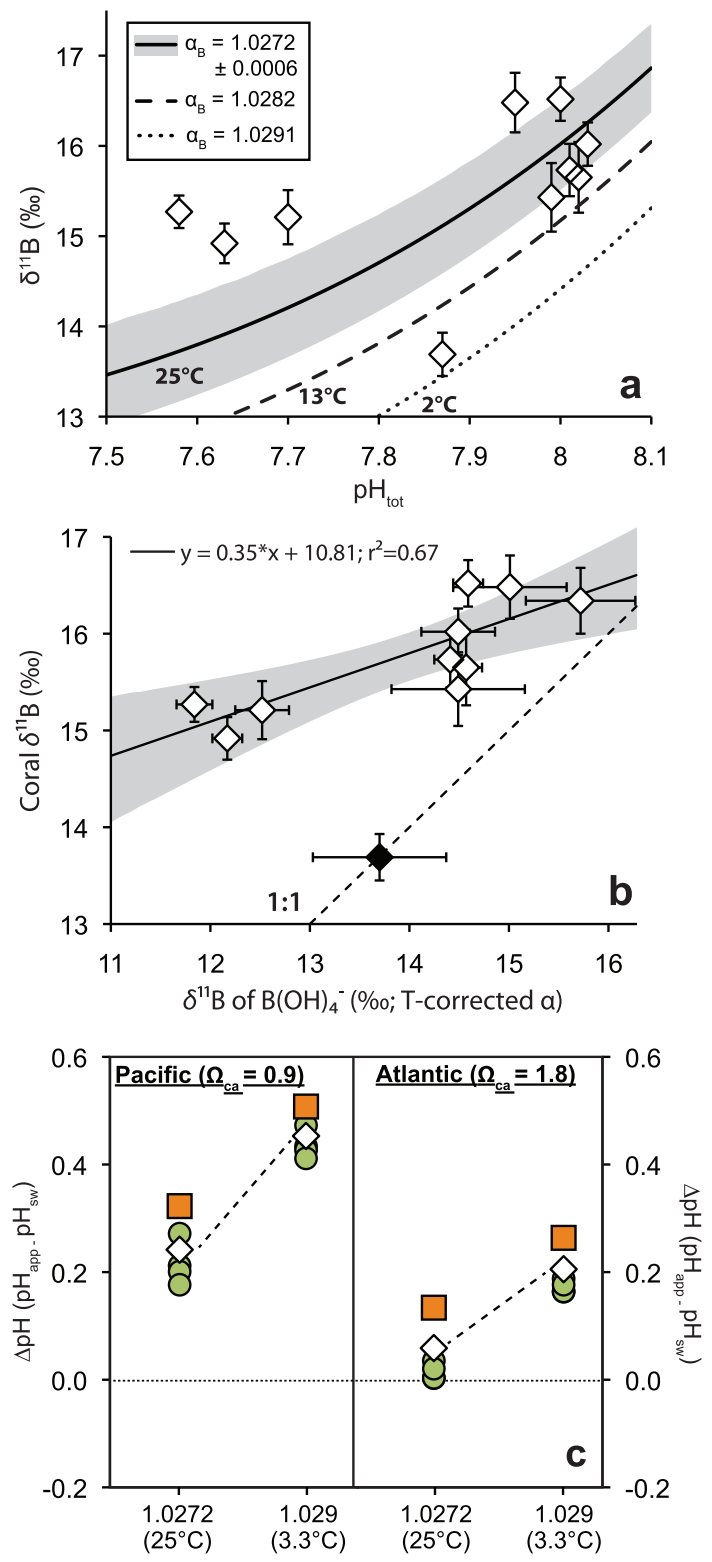

Fig. 9. Influence of the boron isotope fractionation factor on $\delta^{11} \mathrm{~B}_{\text {borate }}$ and $\Delta \mathrm{pH}$. (a) $\delta^{11} \mathrm{~B}_{\text {borate versus }} \mathrm{pH}_{\text {tot }}$ for $\alpha_{\mathrm{B}}=1.0272 \pm 0.0006$ (solid line and gray bound), $\alpha_{\mathrm{B}}=1.0282$ (dashed line, theoretical fractionation factor at $13{ }^{\circ} \mathrm{C}$ ) and $\alpha_{\mathrm{B}}=1.0291$ (dotted line, theoretical fractionation factor at $2{ }^{\circ} \mathrm{C}$ ). Coral surface $\delta^{11} \mathrm{~B}$ data (from Fig. 4) are shown for comparison. (b) Keratoisis surface $\delta^{11} \mathrm{~B}$ versus $\delta^{11} \mathrm{~B}$ of borate anion, with the fractionation factor adjusted for temperature at each collection location. Solid line is least-squares linear regression, with gray shading denoting $\pm 95 \%$ confidence intervals on the regression line. Dashed line is 1:1 line. Specimen 1011762 is indicated by filled diamond and is excluded from the regression. (c) $\Delta \mathrm{pH}$ for (left) Specimen T664-A17 $\left(\Omega_{\text {calcite }}=0.92\right)$ and (right) $27000 \quad\left(\Omega_{\text {cal- }}\right.$ cite $=1.78)$, as calculated using $\alpha_{\mathrm{B}}=1.0272$ and temperaturecorrected $\alpha_{\mathrm{B}}=1.0290$. Symbols and colors in (c) are the same as for Fig. 7. (For interpretation of the references to color in this figure legend, the reader is referred to the web version of this article.)
Although this is an attractive approach, it assumes that the functioning of the boron isotope proxy in marine carbonates is tightly constrained. However, there are several shortcomings in our understanding of boron biogeochemistry that we must consider before calcifier physiology can be inferred from $\delta^{11} \mathrm{~B}$ with confidence. Most importantly, interpreting the deviation from $\delta^{11} \mathrm{~B}_{\text {borate }}$ in terms of $\mathrm{pH}$ adjustment requires $\delta^{11} \mathrm{~B}_{\text {borate }}$ to be accurately determined. Klochko et al. (2006) have quantified the magnitude of aqueous boron isotope fractionation in artificial seawater at $25^{\circ} \mathrm{C}$ and atmospheric pressure. Thermodynamic considerations predict an increase in boron isotope fractionation with decreasing temperature (Fig. 9a; Zeebe, 2005; Rustad et al., 2010), but the empirical results of Klochko et al. (2006) are too variable to confirm or negate a temperature influence on the fractionation factor. Although the magnitude of the temperature effect is poorly constrained (Zeebe, 2005; Rustad et al., 2010), a temperature adjustment to the fractionation factor would be largest for deep-sea samples, which are obtained from much lower temperatures than $25^{\circ} \mathrm{C}$. For instance, Zeebe (2005) estimates a $8.2 \times 10^{-5}$ increase in fractionation factor per decrease in ${ }^{\circ} \mathrm{C}$ (albeit with large uncertainty), which, at face value, equates to an increase in boron isotope fractionation from 1.0272 at $25^{\circ} \mathrm{C}$ to 1.0288 at $5^{\circ} \mathrm{C}$ (see also Hönisch et al., 2008). This effect could be part of the explanation for why some deep-dwelling planktic foraminifers (e.g., Neogloboquadrina pachyderma and $N$. dutertrei, Yu et al., 2013; Foster, 2008) record lower $\delta^{11} \mathrm{~B}$ values than predicted using the aqueous fractionation factor of Klochko et al. (2006); namely, $\delta^{11} \mathrm{~B}_{\text {borate }}$ at the habitat depth may in fact be much lower than the experimental value predicts. Consequently, deep-sea coral and benthic foraminifer $\delta^{11} \mathrm{~B}$ may similarly be elevated by several permil compared to $\delta^{11}$.

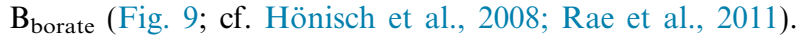
The temperature effect on boron isotope fractionation clearly needs to be determined experimentally, in addition to instrumental analyses of $\mathrm{pH}$ differences in the calcifying microenvironment of deep-sea benthic foraminifers and corals. Furthermore, the $\Delta \mathrm{pH}$ approach is at odds with synthetic calcite, which also shows a lower $\mathrm{pH}$-sensitivity than predicted from aqueous boron isotope fractionation (Fig. 4a; Sanyal et al., 2000; see Henehan et al., 2013). Because biological effects cannot explain the deviation in synthetic calcite, these data provide strong evidence that boron incorporation into marine carbonates is governed by additional effects that have yet to be identified.

To illustrate these caveats, we translate the observed departures of coral $\delta^{11} \mathrm{~B}$ from $\delta^{11} \mathrm{~B}_{\text {borate }}$ (Fig. 7a) to magnitudes of $\mathrm{pH}$ offset between the coral's calcifying microenvironment $\left(\mathrm{pH}_{\mathrm{app}}\right)$ and ambient seawater $\left(\Delta \mathrm{pH}=\mathrm{pH}_{\mathrm{app}}-\mathrm{pH}_{\mathrm{sw}}\right.$, Fig. 7b). All samples from corals collected at $\Omega_{\text {calcite }}<1$ (from the Pacific) show $\mathrm{pH}$ elevation of 0.1 to 0.4 units, with the magnitude of $\mathrm{pH}$ elevation generally increasing with decreasing $\Omega_{\text {calcite }}$. Following the argument outlined by McCulloch et al. (2012), these data would suggest that bamboo corals grow in undersaturated conditions by physiological adjustment of their calcifying microenvironment to more alkaline conditions. $\mathrm{pH}$ elevation in these three corals could also explain the surface 
$\delta^{11} \mathrm{~B}$ values elevated above $\delta^{11} \mathrm{~B}_{\text {borate, }}$ which decreases the $\delta^{11} \mathrm{~B}_{\text {coral }}$ versus $\delta^{11} \mathrm{~B}_{\text {borate }}$ regression slope (Fig. 4b) and may account for the shallowness of this slope relative to other carbonates (Table 4).

Corals collected at $\Omega_{\text {calcite }}>1$ (specimens from the North Atlantic) show $\Delta \mathrm{pH}$ values generally averaging zero, with a range of -0.2 to $+0.2 \mathrm{pH}$ units. Excluding samples taken proximal to the central axis, the highest observed $\Delta \mathrm{pH}$ is less than +0.1 unit, which may suggest that these corals do not appreciably modify their calcifying microenvironment $\mathrm{pH}$ relative to seawater. Negative values for $\Delta \mathrm{pH}$ exceeding $-0.1 \mathrm{pH}$ unit are observed in one of the five specimens with $\Omega_{\text {calcite }}>1$. Similar negative $\Delta \mathrm{pH}$ values (up to -0.2 units) are reconstructed for symbiont-barren versus symbiont-bearing foraminifers, and are hypothesized to reflect the influence of respiration on microenvironment pH (Hönisch et al., 2003). Aside from coral respiration, the negative bamboo coral $\Delta \mathrm{pH}$ data could also be accounted for by an underestimate of the boron isotope fractionation factor at lower temperatures, as described above.

Fig. 9 details how an increased fractionation factor at lower temperatures could complicate interpretation of coral $\delta^{11} \mathrm{~B}$ in terms of quantitative $\mathrm{pH}$ adjustments. At lower temperatures, a larger fractionation factor will lower $\delta^{11} \mathrm{~B}_{\text {borate }}$ over the $\mathrm{pH}$ range of specimens in this study, leading to a positive offset between $\delta^{11} \mathrm{~B}_{\text {coral }}$ and $\delta^{11} \mathrm{~B}_{\text {borate }}$ (Fig. 9a). Using the fractionation factor temperature sensitivity estimated by Zeebe (2005) (cf. Hönisch et al., 2008), we calculate theoretical temperature-corrected fractionation factors for each coral, ranging from 1.0282 at $13{ }^{\circ} \mathrm{C}$ for Specimen 57439 to 1.0291 at $2{ }^{\circ} \mathrm{C}$ for Specimen T668-A13. The relationship between distal skeletal coral $\delta^{11} \mathrm{~B}$ and $\delta^{11} \mathrm{~B}_{\text {borate }}$ calculated using the temperature-corrected fractionation factors is shown in Fig. 9b:

$$
\begin{aligned}
\delta^{11} \mathrm{~B}_{\text {coral }}(\% \mathrm{oo})= & (0.35 \pm 0.17)^{*} \delta^{11} \mathrm{~B}_{\text {borate }} \\
& +(10.81 \pm 2.44)\left(2 \mathrm{SE}, r^{2}=0.67\right)
\end{aligned}
$$

This relationship is statistically indistinguishable from that previously established using $\delta^{11} \mathrm{~B}_{\text {borate }}$ calculated solely from the $25^{\circ} \mathrm{C}$ fractionation factor (Eq. (2), Fig. 4b). However, North Atlantic coral $\delta^{11} \mathrm{~B}$ are more positive than $\delta^{11} \mathrm{~B}_{\text {borate }}$ calculated from the temperature-corrected fractionation, and no longer lie on a 1:1 line (compare Fig. 9b with Fig. 4b). In contrast, Specimen 1011762, which is $1.3 \%$ lower than $\delta^{11} \mathrm{~B}_{\text {borate }}$ calculated from $\alpha_{\mathrm{B}}=1.0272$ at $25^{\circ} \mathrm{C}$ (Fig. 4b), lies on a 1:1 line with $\delta^{11} \mathrm{~B}_{\text {borate }}$ calculated from the temperature-corrected fractionations (Fig. 9b).

Fig. 9c illustrates how a temperature-corrected fractionation changes $\Delta \mathrm{pH}$. Specimens T664-A17 and 27000 were collected at indistinguishable temperatures (3.3 versus $3.33{ }^{\circ} \mathrm{C}$, Table 1) and thus have the same temperature-corrected fractionation (1.0290). $\Delta \mathrm{pH}$ estimates increase by 0.2 $\mathrm{pH}$ units on average with the 1.029 fractionation compared to the 1.0272 fractionation (Fig. 9c). As a result, Atlantic corals now reflect calcification at elevated $\mathrm{pH}$ $(\Delta \mathrm{pH}=+0.2$ units), while the degree of $\mathrm{pH}$ elevation in Pacific corals correspondingly increases up to $+0.5 \mathrm{pH}$ units (Fig. 9c). In summary, even though the temperature sensitivity of the fractionation factor is uncertain and remains to be quantified experimentally, it is clear that the magnitude of calcifying microenvironment $\mathrm{pH}$ elevation assumed from boron isotopes is highly sensitive to changes in the value of $\delta^{11} \mathrm{~B}_{\text {borate }}$, and hence to the boron isotope fractionation factor. Accounting for uncertainty with the measured boron isotope fractionation factor $( \pm 0.0006$, Klochko et al., 2006) alone adds a $\Delta \mathrm{pH}$ uncertainty of greater than 0.1 units. This comparison shows that using geochemical proxies to infer physiological effects is subject to significant uncertainties if the understanding of proxy geochemistry is incomplete.

\subsection{Evidence for ontogenetic variations in bamboo coral calcification}

In contrast to absolute $\Delta \mathrm{pH}$ values, relative differences in $\Delta \mathrm{pH}$ values within single specimens will not be fundamentally altered by changes in the boron isotope fractionation (e.g., Fig. 9c). Elevated $\delta^{11} \mathrm{~B}$ values proximal to the central axes of bamboo corals (Figs. 5, 6 and 7a) are associated with $\mathrm{pH}$ elevations of $\sim 0.1 \mathrm{pH}$ units (ranging from 0 to +0.17 ) relative to the remainder of the coral skeleton in both Pacific and Atlantic specimens (Fig. 7b). A hypothesis for this observation is a higher growth rate in the juvenile stage of bamboo corals. Noé and Dullo (2006) observe solid inclusions, a darker color, and lower length/width ratios in crystals surrounding the central axis conforming to the juvenile growth stage. $\delta^{13} \mathrm{C}$ and $\delta^{18} \mathrm{O}$ behavior near the central axis is equivocal in this study (Figs. 5 and 6), likely due to low sampling resolution. However, Hill et al. (2011) observe more significant depletions in $\delta^{13} \mathrm{C}$ and $\delta^{18} \mathrm{O}$ within several $\mathrm{mm}$ of the central axis of bamboo corals sampled at higher resolution, relative to the remainder of the coral skeleton. Higher $\delta^{11} \mathrm{~B}$ and more negative $\delta^{13} \mathrm{C}$ and $\delta^{18} \mathrm{O}$ near the central axis may be indicative of faster growth, possibly driven by enhanced $\mathrm{pH}$ and calcite saturation in the calcifying microenvironment. Depleted $\delta^{13} \mathrm{C}$ and $\delta^{18} \mathrm{O}$ are observed in calcification centers of scleractinian corals, where low-density aragonite (Adkins et al., 2003) and labeling experiments (Brahmi et al., 2012) independently indicate faster growth, although the role of $\mathrm{pH}$ in the calcification centers is debated (Blamart et al., 2007). Furthermore, elevated $\mathrm{Mg} / \mathrm{Ca}$ is observed both surrounding the central axis of bamboo corals (Thresher et al., 2010; Sinclair et al., 2011) and in the calcification centers of scleractinian corals (Meibom et al., 2004; Gagnon et al., 2007; Brahmi et al., 2012). Although the relationship between $\mathrm{Mg} / \mathrm{Ca}$ and growth rate needs to be tested rigorously, in both cases elevated $\mathrm{Mg} / \mathrm{Ca}$ could be due to a reduced ability of the corals to discriminate against $\mathrm{Mg}$ at higher calcification rates (i.e. surface entrapment, Watson, 1996; Gagnon et al., 2007; DePaolo, 2011, but see Gabitov et al., 2014).

\subsection{Bamboo and scleractinian coral geochemistry: Calcification inferences}

Two observations are insightful for comparing bamboo coral calcification to previous geochemical models for 
scleractinian calcification. First, $\delta^{13} \mathrm{C}$ versus $\delta^{18} \mathrm{O}$ slopes observed in bamboo coral specimens are similar to those observed in scleractinian corals, as previously noted by Hill et al. (2011) and Kimball et al. (2014). At face value, this may suggest that similar processes drive $\delta^{13} \mathrm{C}$ and $\delta^{18} \mathrm{O}$ disequilibria in scleractinian and gorgonian DSC. However, significantly more positive $\delta^{11} \mathrm{~B}$ values are observed in scleractinian DSC relative to the gorgonian corals analyzed here (Fig. 4a), despite similar collection conditions of temperature, salinity, and depth. The $\Delta \mathrm{pH}$ approach implies that the magnitude of $\mathrm{pH}$ elevation in the calcifying microenvironment of bamboo corals is much smaller than that observed for scleractinian DSC (Anagnostou et al., 2012; McCulloch et al., 2012). This $\delta^{11} \mathrm{~B}$ discrepancy likely reflects different calcification mechanisms in gorgonian versus scleractinian corals, and may suggest that $\mathrm{pH}$ elevation in the calcifying microenvironment (Adkins et al., 2003) is not the cause of gorgonian DSC vital effects. Considering uncertainties with the $\Delta \mathrm{pH}$ approach outlined above, a robust quantification of the difference in calcifying microenvironment $\mathrm{pH}$ between these coral groups needs to be obtained through direct observations.

\section{PALEOCEANOGRAPHIC CONSIDERATIONS AND CONCLUSIONS}

The goal of this study was to test whether bamboo coral skeletons can be utilized as archives of past intermediate ocean $\mathrm{pH}$ using the $\delta^{11} \mathrm{~B}$ proxy. We summarize the relevant results here:

1. The geochemistry of Keratoisis specimens is influenced by vital effects, potentially related to active modification of $\mathrm{pH}$ during coral calcification. However, the magnitude of this vital effect appears small compared to scleractinian deep-sea corals. In Keratoisis, $\delta^{11} \mathrm{~B}$ values are elevated in specimens from $\Omega_{\text {calcite }}<1$ by $0.5-2 \%$ relative to $\delta^{11} \mathrm{~B}_{\text {borate, }}$ and elevated in samples near the central axes of specimens by $0.25-1.5 \%$ relative to the rest of the specimen. $\mathrm{pH}$ vital effects may influence these specimens and samples in particular.

2. For specimens from $\Omega_{\text {calcite }}>1$, coral surface $\delta^{11} \mathrm{~B}$ is consistent with $\delta^{11} \mathrm{~B}_{\text {borate }}$ defined using the experimentally determined fractionation factor at $25{ }^{\circ} \mathrm{C}$ (Klochko et al., 2006). Excluding the central axis, magnitudes of $\delta^{11} \mathrm{~B}$ variability within single internodes and across multiple internode surfaces range from $<0.5 \%$ to $1.5 \%$ (Figs. 3 and 5-7). We cannot identify the source of this "noise", and it is potentially large compared to paleoclimatic signals. For comparison, the late Quaternary glacial-interglacial surface ocean $\mathrm{pH}$ change corresponds to a $\sim 1.5 \%$ change in planktic foraminifer $\delta^{11} \mathrm{~B}$ (Hönisch and Hemming, 2005; Henehan et al., 2013).

3. The magnitude of the current ocean acidification signal between 850 and $2000 \mathrm{~m}$ in the North Atlantic (0.030.07 units) is too small to be detected in Keratoisis $\delta^{11} \mathrm{~B}$ relative to uncertainty. Additional studies of bamboo corals from locations with larger anthropogenic carbon inventories, or from past time intervals subject to larger $\mathrm{pH}$ changes, are important for testing the response of bamboo coral $\delta^{11} \mathrm{~B}$ to seawater $\mathrm{pH}$ change. $\mathrm{A} \delta^{11} \mathrm{~B}$ signal of $0.8 \%$ - corresponding to approximately 0.1 $\mathrm{pH}$ units - may be detectable in a specimen with minimal "noise".

4. Interpreting biomineralization mechanisms using $\delta^{11} \mathrm{~B}$ measurements as representative of $\mathrm{pH}$ within the calcifying microenvironment is subject to several important caveats that create a high degree of uncertainty, particularly for deep-sea organisms. Quantification of the temperature influence on boron isotope fractionation and/or experimental determination of the fractionation factor at temperatures typical for the deep sea, and understanding the divergence between the $\delta^{11} \mathrm{~B}-\mathrm{pH}$ relationships observed in synthetic calcite and with the aqueous fractionation are critical to improving this approach. Inorganic precipitation experiments at lower temperatures and calcifying microenvironment $\mathrm{pH}$ measurements in bamboo corals would be particularly useful for understanding these issues.

\section{ACKNOWLEDGEMENTS}

We thank the Smithsonian Institution Department of Invertebrate Zoology and the Yale Peabody Museum Division of Invertebrate Zoology for access to coral specimens, curator Stephen Cairns of the Smithsonian Institution and curator Eric LazoWasem of the Yale Peabody Museum for their assistance obtaining and sampling corals, and Lauren Mullineaux of Woods Hole Oceanographic Institution for her assistance in obtaining coral specimens. California margin specimens were collected in collaboration with the Monterey Bay Aquarium Research Institute and supported by NOAA West Coast Polar Regions Research Program (NA030AR4300104 to T.M.H.) and NSF (OCE 0647872 to T.M.H.). L.F.R. acknowledges support from the Marie Tharp Fellowship at LDEO, ERC grant 278705, a Marie Curie Reintegration Grant and the Philip Leverhulme Trust. We thank Nina Ruprecht and Feng Lu for laboratory assistance, and Samar Khatiwala, Alexander Gagnon, Kat Allen, Jerry McManus, and Peter deMenocal for helpful discussions. We thank three anonymous reviewers and Associate Editor Claire Rollion-Bard for their thoughtful input that greatly improved this manuscript. J.R.F. acknowledges support from the National Science Foundation Graduate Research Fellowship under Grant No. DGE 1144155. This research was funded by NSF OCE 1041133 to B.H.

\section{APPENDIX A. SUPPLEMENTARY DATA}

Electronic annex contains two figures and one table detailing the efficacy of the cleaning procedure and reproducibility of $\delta^{11} \mathrm{~B}$ measurements. Supplementary data associated with this article can be found, in the online version, at http://dx.doi.org/10.1016/j.gca.2015.01.018. 


\section{REFERENCES}

Adkins J. F., Cheng H., Boyle E. A., Druffel E. R. M. and Edwards R. L. (1998) Deep-sea coral evidence for rapid change in ventilation of the deep North Atlantic 15,400 years ago. Science 280(5364), 725-728.

Adkins J., Boyle E., Curry W. and Lutringer A. (2003) Stable isotopes in deep-sea corals and a new mechanism for "vital effects". Geochim. Cosmochim. Acta 67(6), 11291143.

Al-Horani F. A., Al-Moghrabi S. M. and de Beer D. (2003) The mechanism of calcification and its relation to photosynthesis and respiration in the scleractinian coral Galaxea fascicularis. Mar. Biol. 142, 419-426.

Allemand D., Tambutté E., Zoccola D. and Tambutté S. (2011) Coral calcification, cells to reefs. In Coral Reefs: an Ecosystem in Transition (eds. Z. Dubinsky and N. Stambler). Springer, pp. $119-150$.

Allison N. and Finch A. A.EIMF (2010) $\Delta^{11} \mathrm{~B}, \mathrm{Sr}, \mathrm{Mg}$ and $\mathrm{B}$ in a modern Porites coral: the relationship between calcification site $\mathrm{pH}$ and skeletal chemistry. Geochim. Cosmochim. Acta 74, 1790-1800. http://dx.doi.org/10.1016/j.gca.2009.12.030.

Anagnostou E., Sherrell R. M., Gagnon A., LaVigne M., Field M. P. and McDonough W. F. (2011) Seawater nutrient and carbonate ion concentrations recorded as $\mathrm{P} / \mathrm{Ca}, \mathrm{Ba} / \mathrm{Ca}$, and $\mathrm{U} /$ $\mathrm{Ca}$ in the deep-sea coral Desmophyllum dianthus. Geochim. Cosmochim. Acta 75. http://dx.doi.org/10.1016/j.gca.2011. 02.019 .

Anagnostou E., Huang K., You C., Sikes E. and Sherrell R. (2012) Evaluation of boron isotope ratio as a $\mathrm{pH}$ proxy in the deep sea coral Desmophyllum dianthus: evidence of physiological $\mathrm{pH}$ adjustment. Earth Planet. Sci. Lett. 349-350. http://dx.doi.org/ 10.1016/j.eps1.2012.07.006.

Antonov J. I., Seidov D., Boyer T. P., Locarnini R. A., Mishono A. V. and Garcia H. E. (2010) World ocean atlas 2009, volume 2: salinity. In NOAA Atlas NESDIS 69 (ed. S. Levitus). U.S. Government Printing Office, Washington, D.C., 184 pp.

Bates N. R. (2007) Interannual variability of the oceanic $\mathrm{CO}_{2}$ sink in the subtropical gyre of the North Atlantic ocean over the last 2 decades. J. Geophys. Res. 112, C09013. http://dx.doi.org/ 10.1029/2006JC003759.

Blamart D., Rollion-Bard C., Meibom A., Cuif J.-P., JuilletLeclerc A. and Dauphin Y. (2007) Correlation of boron isotopic composition with ultrastructure in the deep-sea coral Lophelia pertusa: implications for biomineralization and paleopH. Geochem. Geophys. Geosyst. 8(12). http://dx.doi.org/ 10.1029/2007GC001686.

Brahmi C., Kopp C., Domart-Coulon I., Stolarski J. and Meibom A. (2012) Skeletal growth dynamics linked to trace-element composition in the scleractinian coral Pocillopora damicornis. Geochim. Cosmochim. Acta 99. http://dx.doi.org/10.1016/ j.gca.2012.09.031.

Burke A. and Robinson L. (2012) The southern ocean's role in carbon exchange during the last deglaciation. Science 335(6068), 557-561. http://dx.doi.org/10.1126/science.1208163.

Caldeira K. and Wickett M. E. (2003) Anthropogenic carbon and ocean pH. Nature 425, 365.

Case D. H., Robinson L. F., Auro M. E. and Gagnon A. C. (2010) Environmental and biological controls on $\mathrm{Mg}$ and $\mathrm{Li}$ in deepsea scleractinian corals. Earth Planet. Sci. Lett. 300, 215-225. http://dx.doi.org/10.1016/j.eps1.2010.09.029.

Catanzaro E., Champion C., Garner E., Marinenko G., Sappenfield K. and Shields W. (1970) Boric acid: isotopic and assay standard reference materials. National Bureau of Standards (USA) Spec. Publ. 260-17, 1-70.
Cohen A. L. and McConnaughey T. (2003) Geochemical perspectives on coral mineralization. Rev. Mineral. Geochem. 54, 151187.

DePaolo D. J. (2011) Surface kinetic model for isotopic and trace element fractionation during precipitation of calcite from aqueous solutions. Geochim. Cosmochim. Acta 75, 1039-1056. http://dx.doi.org/10.106/j.gca.2010.11.020.

Dickson A. G. (1990) Thermodynamics of the dissociation of boric acid in synthetic seawater from 273.15 to 318.15 K. Deep Sea Res. Part A 37(5), 755-766.

Doney S., Fabry V., Feely R. and Kleypas J. (2009) Ocean acidification: the other $\mathrm{CO}_{2}$ problem. Annu. Rev. Mar. Sci. 1, 169-192. annurev.marine.010908.163834.

http://dx.doi.org/10.1146/

Dore J. E., Lukas R., Sadler D. W., Church M. J. and Karl D. M. (2009) Physical and biogeochemical modulation of ocean acidification in the central North Pacific. PNAS 106(30), 12235-12240. http://dx.doi.org/10.1073/pnas.0906044106.

Emiliani C., Hudson J. H., Shinn E. A. and George R. Y. (1978) Oxygen and carbon isotopic growth record in a reef coral from the Florida keys and a deep-sea coral from Blake Plateau. Science 202, 627-629.

Feely R., Sabine C., Lee K., Berelson W., Kleypas J., Fabry V. and Millero F. (2004) Impact of anthropogenic $\mathrm{CO}_{2}$ on the $\mathrm{CaCO}_{3}$ system in the oceans. Science 305(5682), 362-366. http:// dx.doi.org/10.1126/science.1097329.

Foster G. L. (2008) Seawater $\mathrm{pH}, \mathrm{pCO}_{2}$ and $\left[\mathrm{CO}_{3}^{2-}\right]$ variations in the Caribbean Sea over the last $130 \mathrm{kyr}$ : A boron isotope and $\mathrm{B} /$ Ca study of planktic foraminifera. Earth Planet. Sci. Lett. 271, 254-266. http://dx.doi.org/10.1016/j.eps1.2008.04.015.

Foster G. L., Pogge von Strandmann P. A. E. and Rae J. W. (2010) Boron and magnesium isotopic composition of seawater. Geochim. Geophys. Geosyst. 11, Q08015.

Foster G. L., Hönisch B., Paris G., Dwyer G. S., Rae J. W. B., Elliott T., Gaillardet J., Hemming N. G., Louvat P. and Vengosh A. (2013) Interlaboratory comparison of boron isotope analyses of boric acid, seawater and marine $\mathrm{CaCO}_{3}$ by MC-ICPMS and NTIMS. Chem. Geol. 358, 1-14. http:// dx.doi.org/10.1016/j.chemgeo.2013.08.027.

Frank N., Paterne M., Ayliffe L., van Weering T., Henriet J.-P. and Blamart D. (2004) Eastern North Atlantic deep-sea corals: tracing upper intermediate water $\Delta^{14} \mathrm{C}$ during the Holocene. Earth Planet. Sci. Lett. 219, 297-309.

Gabitov R. I., Sadekov A. and Leinweber A. (2014) Crystal growth rate effect on $\mathrm{Mg} / \mathrm{Ca}$ and $\mathrm{Sr} / \mathrm{Ca}$ partitioning between calcite and fluid: an in situ approach. Chem. Geol. 367, 70-82. http:// dx.doi.org/10.1016/j.chemgeo.2013.12.019.

Gagnon A. C., Adkins J. F., Fernandez D. P. and Robinson L. F. (2007) $\mathrm{Sr} / \mathrm{Ca}$ and $\mathrm{Mg} / \mathrm{Ca}$ vital effects correlated with skeletal architecture in a scleractinian deep-sea coral and the role of Rayleigh fractionation. Earth Planet. Sci. Lett. 261. http:// dx.doi.org/10.1016/j.eps1.2007.07.013.

González-Dávila M., Santana-Casiano J. M., Rueda M. J. and Llinás O. (2010) The water column distribution of carbonate system variables at the ESTOC site from 1995 to 2004. Biogeosciences 7. http://dx.doi.org/10.5194/bg-7-3067-2010.

Grottoli A. G., Rodrigues L. J., Matthews K. A., Palardy J. E. and Gibb O. T. (2005) Pre-treatment effects on coral skeletal $\delta^{13} \mathrm{C}$ and $\delta^{18} \mathrm{O}$. Chem. Geol. 221, 225-242.

Gruber N. (1998) Anthropogenic $\mathrm{CO}_{2}$ in the Atlantic Ocean. Global Biogeochem. Cycles 12, 165-191.

Hemming N. G. and Hanson G. N. (1994) A procedure for the isotopic analysis of boron by negative thermal ionization mass spectrometry. Chem. Geol. 114, 147-156.

Henehan M. J., Rae J. W. B., Foster G. L., Erez J., Prentice K. C., Kucera M., Bostock H. C., Martínez-Botí M. A., Milton J. A., 
Wilson, Marshall B. J. and Elliott T. (2013) Calibration of the boron isotope proxy in the planktonic foraminifera Globigerinoides ruber for use in palaeo- $\mathrm{CO}_{2}$ reconstruction. Earth Planet. Sci. Lett. 364, 111-122.

Hill T. M., Spero H. J., Guilderson T., LaVigne M., Clague D., Macalello S. and Jang N. (2011) Temperature and vital effect controls on bamboo coral (isididae) isotope geochemistry: a test of the "lines method". Geochem. Geophys. Geosyst. 12(4). http://dx.doi.org/10.1029/2010GC003443.

Hill T. M., LaVigne M., Spero H. J., Guilderson T., Gaylord B. and Clague D. (2012) Variations in seawater $\mathrm{Sr} / \mathrm{Ca}$ recorded in deep-sea bamboo corals. Paleoceanography 27. http:// dx.doi.org/10.1029/2011PA002260.

Hönisch B. and Hemming N. G. (2005) Surface ocean pH response to variations in $\mathrm{pCO}_{2}$ through two full glacial cycles. Earth Planet. Sci. Lett. 236, 305-314.

Hönisch B., Bijma J., Russell A. D., Spero H. J., Palmer M. R., Zeebe R. E. and Eisenhauer A. (2003) The influence of symbiont photosynthesis on the boron isotopic composition of foraminifera shells. Mar. Micropaleontol. 49, 87-96.

Hönisch B., Hemming N. G., Grottoli A. G., Amat A., Hanson G. N. and Bijma J. (2004) Assessing scleractinian corals as recorders for paleo-pH: empirical calibration and vital effects. Geochim. Cosmochim. Acta 68(18), 3675-3685.

Hönisch B., Bickert T. and Hemming N. G. (2008) Modern and Pleistocene boron isotope composition of the benthic foraminifer Cibicoides wuellerstorfi. Earth Planet. Sci. Lett. 272, 309318 .

Keeling C. D. (1979) The Suess effect: ${ }^{13}$ Carbon $-{ }^{14}$ Carbon interrelations. Environ. Int. 2, 229-300.

Key R. M., Kozyr A., Sabine C. L., Lee K., Wanninkhof R., Bullister J. L., Feely R. A., Millero F. J., Mordy C. and Peng T.-H. (2004) A global ocean carbon climatology: results from global data analysis project (GLODAP). Global Biogeochem. Cycles 18. http://dx.doi.org/10.1029/2004GB002247.

Khatiwala S., Primeau F. and Hall T. (2009) Reconstruction of the history of anthropogenic $\mathrm{CO}_{2}$ concentrations in the ocean. Nature 462(7271), 346-349. http://dx.doi.org/ 10.1038/nature08526.

Kimball J. B., Dunbar R. B. and Guilderson T. P. (2014) Oxygen and carbon fractionation in calcitic deep-sea corals: implications for paleotemperature reconstruction. Chem. Geol. 381. http://dx.doi.org/10.1016/j.chemgeo.2014.05.008.

Klochko K., Kaufman A. J., Yao W., Byrne R. H. and Tossell J. A. (2006) Experimental measurement of boron isotope fractionation in seawater. Earth Planet. Sci. Lett. 248. http:// dx.doi.org/10.1016/j.epsl.2006.05.034.

Körtzinger A., Quay P. D. and Sonnerup R. E. (2003) Relationship between anthropogenic $\mathrm{CO}_{2}$ and the ${ }^{13} \mathrm{C}$ Suess effect in the North Atlantic ocean. Global Biogeochem. Cycles 17, 1005. http://dx.doi.org/10.1029/2001GB001427.

Krief S., Hendy E. J., Fine M., Yam R., Meibom A., Foster G. L. and Shemesh A. (2010) Physiological and isotopic responses of scleractinian corals to ocean acidification. Geochim. Cosmochim. Acta 74. http://dx.doi.org/10.1016/j.gca.2010.05.023.

Kroopnick P. (1980) The distribution of ${ }^{13} \mathrm{C}$ in the Atlantic ocean. Earth Planet. Sci. Lett. 49(2), 469-484.

LaVigne M., Hill T. M., Spero H. J. and Guilderson T. P. (2011) Bamboo coral $\mathrm{Ba} / \mathrm{Ca}$ : calibration of a new deep ocean refractory nutrient proxy. Earth Planet. Sci. Lett. 312. http:// dx.doi.org/10.1016/j.epsl.2011.10.013.

LeBel D. A., Smethie, Jr., W. M., Rhein M., Kieke D., Fine R. A., Bullister J. L., Min D.-H., Roether W., Weiss R. F., Andrié C., Smythe-Wright D. and Jones E. P. (2008) The formation rate of North Atlantic deep water and eighteen degree water calculated from CFC-11 inventories observed during WOCE. Deep-Sea Res. I 55, 891-910. http://dx.doi.org/10.1016/j.dsr.2008.03.009.

Lee K., Kim T.-W., Byrne R. H., Millero F. J., Feely R. A. and Liu Y.-M. (2010) The universal ratio of boron to chlorinity for the North Pacific and North Atlantic oceans. Geochim. Cosmochim. Acta 74(6), 1801-1811.

LeGrande A. N. and Schmidt G. A. (2006) Global gridded data set of the oxygen isotopic composition in seawater. Geophys. Res. Lett. 33.

Locarnini R. A., Mishonov A. V., Antonov J. I., Boyer T. P. and Garcia H. E. (2010) World ocean atlas 2009, volume 1: temperature. In NOAA Atlas NESDIS 68 (ed. S. Levitus). U.S. Government Printing Office, Washington, D.C., 184 pp.

López Correa M., Montagna P., Vendrell-Simón B., McCulloch M. and Taviani M. (2010) Stable isotopes $\left(\delta^{13} \mathrm{C}\right.$ and $\left.\delta^{18} \mathrm{O}\right)$, trace and minor element compositions of recent scleractinians ad last glacial bivalves at the Santa Maria di Leuca deep-water coral province, Ionian Sea. Deep-Sea Res. II 57, 471-486. http://dx.doi.org/10.1016/j.dsr2.2009.08.016.

Lueker T. J., Dickson A. G. and Keeling C. D. (2000) Ocean $p \mathrm{CO}_{2}$ calculated from dissolved inorganic carbon, alkalinity, and equations for $K_{1}$ and $K_{2}$ : validation based on laboratory measurements of $\mathrm{CO}_{2}$ in gas and seawater at equilibrium. Mar. Chem. 70, 105-119.

Lutringer A., Blamart D., Frank N. and Labeyrie L. (2005) Paleotemperatures from deep-sea corals: scale effects. In ColdWater Corals and Ecosystems (eds. A. Friewald and J. M. Roberts). Springer-Verlag, Berlin Heidelberg, pp. 1081-1096.

McConnaughey T. (1989) ${ }^{13} \mathrm{C}$ and ${ }^{18} \mathrm{O}$ isotopic disequilibrium in biological carbonates: I. Patterns. Geochim. Cosmochim. Acta 53, 151-162.

McCulloch M., Trotter J., Montagna P., Falter J., Dunbar R., Freiwald A., Fórsterra G., Correa M. L., Maier C., Rùggeberg A. and Taviani M. (2012) Resilience of cold-water scleractinian corals to ocean acidification: boron isotopic systematics of $\mathrm{pH}$ and saturation state up-regulation. Geochim. Cosmochim. Acta 87. http://dx.doi.org/10.1016/j.gca.2012.03.027.

Meibom A., Cuif J.-P., Hillion F., Constantz B. R., Juillet-Leclerc A., Dauphin Y., Watanabe T. and Dunbar R. B. (2004) Distribution of magnesium in coral skeleton. Geophys. Res. Lett. 31, L23306. http://dx.doi.org/10.1029/2004GL021313.

Millero F. (1995) Thermodynamics of the carbon dioxide system in the oceans. Geochim. Cosmochim. Acta 59(4), 661-677.

Montagna P., McCulloch M., Taviani M., Mazzoli C. and Vendrell B. (2006) Phosphorus in cold-water corals as a proxy for seawater nutrient chemistry. Science 312(5781), 1788-1791.

Montagna P., McCulloch M., Douville E., López Correa M., Trotter J., Rodolfo-Metalpa R., Dissard D., Ferrier-Pagès C., Frank N., Freiwald A., Goldstein S., Mazzoli C., Reynaud S., Rüggeberg A., Russo S. and Taviani M. (2014) Li/Mg systematics in scleractinian corals: calibration of the thermometer. Geochim. Cosmochim. Acta 132, 288-310. http://dx.doi.org/ 10.1016/j.gca.2014.02.005.

Noé S. U. and Dullo W.-C. (2006) Skeletal morphogenesis and growth mode of modern and fossil deep-water isidid gorgonians (octocorallia) in the west Pacific (New Zealand and Sea of Okhotsk). Coral Reefs 25, 303-320.

Ogilvie M. M. (1896) Microscopic and systematic study of madreporarian types of corals. Philos. Trans. R. Soc. Lond. B 187, 83-345.

Olsen A. and Ninnemann U. (2010) Large $\delta^{13} \mathrm{C}$ gradients in the preindustrial North Atlantic revealed. Science 330. http:// dx.doi.org/10.1126/science.1193769.

Pelejero C., Calvo E., McCulloch M. T., Marshall J. F., Gagan M. K., Lough J. M. and Opdyke B. N. (2005) Preindustrial to 
modern interdecadal variability in coral reef $\mathrm{pH}$. Science 309, 2204-2207. http://dx.doi.org/10.1126/science.1113692.

Penman D. E., Hönisch B., Rasbury E. T., Hemming N. G. and Spero H. J. (2013) Boron, carbon, and oxygen isotopic composition of brachiopod shells: intra-shell variability, controls, and potential as a paleo-pH recorder. Chem. Geol. 340, 32-39.

Rae J. W., Foster G. L., Schmidt D. N. and Elliott T. (2011) Boron isotopes and $\mathrm{B} / \mathrm{Ca}$ in benthic foraminifera: proxies for the deep ocean carbonate system. Earth Planet. Sci. Lett. 302. http:// dx.doi.org/10.1016/j.eps1.2010.12.034.

Raitzsch M., Hathorne E. C., Kuhnert H., Groeneveld J. and Bicket T. (2011) Modern and late Pleistocene B/Ca ratios of the benthic foraminifer Planulina wuellerstorfi determined with laser ablation ICP-MS. Geology 39(11), 1039-1042. http:// dx.doi.org/10.1130/G32009.1.

Reynaud S., Hemming N. G., Juillet-Leclerc A. and Gattuso J.-P. (2004) Effect of $p \mathrm{CO}_{2}$ and temperature on the boron isotopic composition of the zooxanthellate coral Acropora sp. Coral Reefs 23, 539-546.

Roark E. B., Guilderson T. P., Flood-Page S., Dunbar R. B., Ingram B. L., Fallon S. J. and McCulloch M. (2005) Radiocarbon-based ages and growth rates of bamboo corals from the Gulf of Alaska. Geophys. Res. Lett. 32. http://dx.doi.org/ 10.1029/2004GL021919.

Robinson L., Adkins J., Keigwin L., Southon J., Fernandez D., Wang S. and Scheirer D. (2005) Radiocarbon variability in the western North Atlantic during the last deglaciation. Science 310(5753), 1469-1473. http://dx.doi.org/10.1126/science. 1114832.

Robinson L. F., Adkins J. F., Frank N., Gagnon A. C., Prouty N., Roark E. B. and van de Flierdt T. (2014) The geochemistry of deep-sea coral skeletons: a review of vital effects and applications for palaeoceanography. Deep-Sea Res. II 99, 184-198, doi:10.1016.j.dsr2.2013.06.005.

Rollion-Bard C., Blamart D., Cuif J.-P. and Juillet-Leclerc A. (2003a) Microanalysis of $\mathrm{C}$ and $\mathrm{O}$ isotopes of azooxanthellate and zooxanthellate corals by ion microprobe. Coral Reefs $\mathbf{2 2}$, 405-415.

Rollion-Bard C., Chaussidon M. and France-Lanord C. (2003b) $\mathrm{PH}$ control on oxygen isotopic composition of symbiotic corals. Earth Planet. Sci. Lett. 215, 275-288.

Rollion-Bard C., Vigier N., Meibom A., Blamart D., Reynaud S., Rodolfo-Metalpa R., Martin S. and Gattuso J. (2009) Effect of environmental conditions and skeletal ultrastructure on the $\mathrm{Li}$ isotopic composition of scleractinian corals. Earth Planet. Sci. Lett. 286. http://dx.doi.org/10.1016/j.eps1.2009.06.015.

Rollion-Bard C., Chaussidon M. and France-Lanord C. (2011) Biological control of internal $\mathrm{pH}$ in scleractinian corals: implications on paleo-pH and temperature reconstructions. $C$. R. Geoscience 343, 397-405.

Rustad J. R., Bylaska E. J., Jackson V. E. and Dixon D. A. (2010) Calculation of boron-isotope fractionation between $\mathrm{B}(\mathrm{OH})_{3}$ (aq) and $\mathrm{B}(\mathrm{OH})_{4}^{-}(\mathrm{aq})$. Geochim. Cosmochim. Acta 74, 28432850.

Sabine C., Feely R., Gruber N., Key R., Lee K., Bullister J., Wanninkhof R., Wong C., Wallace D., Tilbrook B., Millero F., Peng T., Kozyr A., Ono T. and Rios A. (2004) The oceanic sink for anthropogenic $\mathrm{CO}_{2}$. Science 305(5682), 367-371. http:// dx.doi.org/10.1126/science.1097403.

Sabine C. L. and Tanhua T. (2010) Estimation of anthropogenic $\mathrm{CO}_{2}$ inventories in the ocean. Annu. Rev. Mar. Sci. 2, 175-198. http://dx.doi.org/10.1146/annurev-marine-120308-080947.

Sanyal A., Hemming N. G., Broecker W. S., Lea D. W., Spero H. J. and Hanson G. N. (1996) Oceanic pH control on the boron isotopic composition of foraminifera: evidence from culture experiments. Paleoceanography 11, 513-517.

Sanyal A., Nugent M., Reeder R. J. and Bijma J. (2000) Seawater $\mathrm{pH}$ control on the boron isotopic composition of calcite: evidence from inorganic calcite precipitation experiments. Geochim. Cosmochim. Acta 64(9), 1551-1555.

Sanyal A., Bijma J., Spero H. and Lea D. W. (2001) Empirical relationship between $\mathrm{pH}$ and the boron isotopic composition of Globigerinoides sacculifer: implications for the boron isotope paleo-pH proxy. Paleoceanography 16, 515-519.

Schlitzer R. (2014) Ocean Data View. Available from: <http://odv. awi.de>.

Sherwood O. A., Heikoop J. M., Scott D. B., Risk M. J., Gulderson T. P. and McKinney R. A. (2005) Stable isotopic composition of deep-sea gorgonian corals Primnoa spp.: a new archive of surfasse processes. Mar. Ecol. Prog. Ser. 301, 135148.

Sherwood O. A., Edinger E. N., Guilderson T. P., Ghaleb B., Risk M. J. and Scott D. B. (2008) Late Holocene radiocarbon variability in Northwest Atlantic slope waters. Earth Planet. Sci. Lett. 275, 146-153.

Sherwood O. A., Lehmann M. F., Schubert C. J., Scott D. B. and McCarty M. D. (2011) Nutrient regime shift in the western North Atlantic indicated by compound-specific $\delta^{15} \mathrm{~N}$ of deepsea gorgonian corals. Proc. Natl. Acad. Sci. U.S.A. 108. http:// dx.doi.org/10.1073/pnas.1004904108.

Sherwood O. A. and Edinger E. N. (2009) Ages and growth rates of some deep-sea gorgonian and antipatharian corals of Newfoundland and Labrador. Can. J. Fish. Aquat. Sci. 66. http:// dx.doi.org/10.1139/F08-195.

Sigman D., Hain M. and Haug G. (2010) The polar ocean and glacial cycles in atmospheric $\mathrm{CO}_{2}$ concentration. Nature 466(7302), 47-55. http://dx.doi.org/10.1038/nature09149.

Sinclair D. J. (2005) Correlated trace element "vital effects" in tropical corals: a new geochemical tool for probing biomineralization. Geochim. Cosmochim. Acta 69. http://dx.doi.org/ 10.1016/j.gca.2005.02.030.

Sinclair D. J., Williams B., Allard G., Ghaleb B., Fallon S., Ross S. and Risk M. (2011) Reproducibility of trace element profiles in a specimen of the deep-water bamboo coral Keratoisis sp. Geochim. Cosmochim. Acta 75. http://dx.doi.org/10.1016/ j.gca.2011.05.012.

Smith J. E., Schwarcz H. P., Risk M. J., McConnaughey T. A. and Keller N. (2000) Paleotemperatures from deep-sea corals: overcoming 'vital effects'. Palaios 15(1), 25-32.

Thresher R. E. (2009) Environmental and compositional correlates of growth rate in deep-water bamboo corals (Gorgonacea; Isididae). Mar. Ecol. Prog. Ser. 397, 187-196. http://dx.doi.org/ 10.3354/meps08245.

Thresher R., Rintoul S. R., Koslow J. A., Weidman C., Adkins J. and Proctor C. (2004) Oceanic evidence of climate change in southern Australia over the last three centuries. Geophys. Res. Lett. 31, L07212. http://dx.doi.org/10.1029/2003GL018869.

Thresher R. E., Wilson N. C., MacRae C. M. and Neil H. (2010) Temperature effects on the calcite skeletal composition of deepwater gorgonians (Isididae). Geochim. Cosmochim. Acta 74. http://dx.doi.org/10.1016/j.gca.2010.05.024.

Thresher R., Tilbrook B., Fallon S., Wilson N. and Adkins J. (2011) Effects of chronic low carbonate saturation levels on the distribution, growth and skeletal chemistry of deep-sea corals and other seamount megabenthos. Mar. Ecol. Prog. Ser. 442. http://dx.doi.org/10.3354/meps09400.

Trotter J., Montagna P., McCulloch M., Silenzi S., Reynaud S., Mortimer G., Martin S., Ferrier-Pagès C., Gattuso J. and Rodolfo-Metalpa R. (2011) Quantifying the $\mathrm{pH}$ 'vital effect' in 
the temperate zooxanthellate coral Cladocora caespitosa: validation of the boron seawater $\mathrm{pH}$ proxy. Earth Planet. Sci. Lett. 303. http://dx.doi.org/10.1016/j.eps1.2011.01.030.

van de Flierdt T., Robinson L. F. and Adkins J. F. (2010) Deep-sea coral aragonite as a recorder for the neodymium isotopic composition of seawater. Geochim. Cosmochim. Acta 74. http:// dx.doi.org/10.1016/j.gca.2010.08.001.

van Heuven S., Pierrot D., Lewis E. and Wallace D. W. R. (2011) MATLAB Program Developed for $\mathrm{CO}_{2}$ System Calculations. ORNL/CDIAC-105b, Carbon Dioxide Information Analysis Center, Oak Ridge National Laboratory, U. S. Department of Energy, Oak Ridge, Tennessee. http://dx.doi.org/10.3334/ CDIAC/otg.CO2SYS_MATLAB_v1.1.

Venn A., Tambutté E., Holcomb M., Allermand D. and Tambutté S. (2011) Live tissue imaging shows reef corals elevate $\mathrm{pH}$ under their calcifying tissue relative to seawater. PLoS One 6(5), e20013.

Venn A. A., Tambutté E., Holcomb M., Laurent J., Allemand D. and Tambutté S. (2013) Impact of seawater acidification on $\mathrm{pH}$ at the tissue-skeleton interface and calcification in reef corals. Proc. Natl. Acad. Sci. U.S.A. 110, 1634-1639.

Verrill A. (1885) Results of the explorations made by the steamer "Albatross" off the northern coast of the United States in 1883. In The Annual Report for the Commissioner of Fish and Fisheries 1883. U.S. Government Printing Office, Washington, D.C.

Wanninkhof R., Park G.-H., Takahashi T., Feely R. A., Bullister J. L. and Doney S. C. (2013) Changes in deep-water $\mathrm{CO}_{2}$ concentrations over the last several decades determined from discrete $p \mathrm{CO}_{2}$ measurements. Deep Sea Res. Part I 74, 48-63. http://dx.doi.org/10.1016/j.dsr.2012.12.005.
Watling L., France S. C., Pante E. and Simpson A. (2011) Biology of deep-water octocorals. Adv. Mar. Biol. 60, 41-122. http:// dx.doi.org/10.1016/B978-0-12-385529-0.00002-0.

Watson E. B. (1996) Surface enrichment and trace-element uptake during crystal growth. Geochim. Cosmochim. Acta 60, 50135020.

Wei G., McCulloch M. T., Mortimer G., Deng W. and Xie L. (2009) Evidence for ocean acidification in the Great Barrier Reef of Australia. Geochim. Cosmochim. Acta 73, 2332-2346. http://dx.doi.org/10.1016/j.gca.2009.02.009.

Yu J., Foster G. L., Elderfield H., Broecker W. S. and Clark E. (2010) An evaluation of benthic foraminiferal $\mathrm{B} / \mathrm{Ca}$ and $\delta^{11} \mathrm{~B}$ for deep ocean carbonate ion and $\mathrm{pH}$ reconstructions. Earth Planet. Sci. Lett. 293, 114-120.

Yu J., Thornalley D. J. R., Rae J. W. B. and McCave N. I. (2013) Calibration and application of $\mathrm{B} / \mathrm{Ca}, \mathrm{Cd} / \mathrm{Ca}$, and $\delta 11 \mathrm{~B}$ in Neogloboquadrina pachyderma (sinistral) to constrain $\mathrm{CO}_{2}$ uptake in the subpolar North Atlantic during the last deglaciation. Paleoceanography 28. http://dx.doi.org/10.1002/palo. 20024.

Zeebe R. E. (2005) Stable boron isotope fractionation between dissolved $\mathrm{B}(\mathrm{OH})_{3}$ and $\mathrm{B}(\mathrm{OH})_{4}^{-}$. Geochim. Cosmochim. Acta 69(11), 2753-2766.

Zeebe R. (2014) Kinetic fractionation of carbon and oxygen isotopes during hydration of carbon dioxide. Geochim. Cosmochim. Acta 139, 540-552. http://dx.doi.org/10.1016/ j.gca.2014.05.005.

Associate editor: Claire Rollion-Bard 